\title{
Impact of copper sulfate application at an urban Brazilian reservoir: A geostatistical and ecotoxicological approach
}

\author{
P.R. Leal ${ }^{\mathrm{a}, *}$, V. Moschini-Carlos ${ }^{\mathrm{c}}$, J.C. López-Doval ${ }^{\mathrm{b}}$, J.P. Cintra ${ }^{\mathrm{a}}$, J.K. Yamamoto ${ }^{\text {a }}$, M.D. Bitencourt ${ }^{\mathrm{a}}$, R.F. Santos ${ }^{\mathrm{a}}$, \\ G.C. Abreu ${ }^{a}$, M.L.M. Pompêo ${ }^{a}$ \\ a University of São Paulo, Ecology, Rua do Matão, 05508-090 São Paulo, Cidade Universitária, Brazil \\ b Catalan Institute for Water Research (ICRA), Carrer Emili Grahit 101, 17003 Girona, Spain \\ c São Paulo State University -UNESP, Environmental Sciences Program, Avenida Três de Março 511, 18087-180 Sorocaba, SP, Brazil
}

\section{H I G H L I G H T S}

- An evaluation of a surficial sediment ecotoxicity of a reservoir is proposed.

- Analysis is based on sediment chemical analysis; geoprocessing; geostatistics; SQGs.

- Impacts of the reservoir's management policy is undertaken.

- Data shows the effect of the reservoir's management policy over its ecotoxicity.

\section{A R T I C L E I N F O}

\section{Article history:}

Received 24 February 2017

Received in revised form 8 June 2017

Accepted 11 July 2017

Available online 18 October 2017

Editor: D. Barcelo

\section{Keywords:}

Landscape ecotoxicology

Sediment

Copper sulfate

Reservoir management policy

Geostatistics

\section{G R A P H I C A L A B S T R A C T}

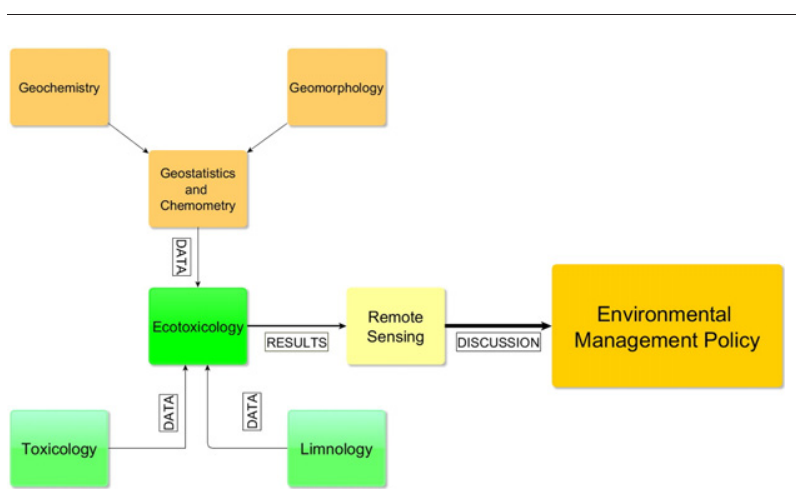

\begin{abstract}
A B S T R A C T
A landscape ecotoxicology approach was used to assess the spatial distribution of copper in the recent bottom sediment (surficial sediment) of a Brazilian subtropical reservoir (the Guarapiranga reservoir) and its potential ecotoxicological impacts on the reservoir ecosystem and the local society. We discuss the policies and procedures that have been employed for the management of this reservoir over the past four decades. Spatial heterogeneity in the reservoir was evaluated by means of sampling design and statistical analysis based on kriging spatial interpolation. The sediment copper concentrations have been converted into qualitative categories in order to interpret the reservoir quality and the impacts of management policies. This conversion followed the Canadian Water Framework Directive (WFD) ecotoxicological concentration levels approach, employing sediment quality guidelines (SQGs). The SQG values were applied as the copper concentration thresholds for quantitative-qualitative conversion of data for the surficial sediment of the Guarapiranga. The SQGs used were as follows: a) interim sediment quality guideline (ISQG), b) probable effect level (PEL), and c) regional reference value (RRV). The quantitative results showed that the spatial distribution of copper in the recent bottom sediment reflected the reservoir's management policy and the copper application protocol, and that the copper concentrations varied considerably, ranging from virtually-zero to in excess of $3 \mathrm{~g}_{\text {copper }} / \mathrm{kg}_{\mathrm{ds}}$. The qualitative results demonstrated that the recent bottom sediment was predominantly in a bad or very bad condition, and could therefore have impacts on the local society and the ecosystem. It could be concluded that the management policy for this reservoir was mainly determined by the desire to minimize short-term costs, disregarding long-term socioeconomic and environmental consequences.
\end{abstract}

(c) 2017 Published by Elsevier B.V.

\footnotetext{
* Corresponding author.

E-mail address: philipe.leal@inpe.br (P.R. Leal).
} 


\section{Introduction}

The eutrophication of water sources is a serious problem in many regions worldwide, requiring the urgent attention of researchers and environmental managers (Margalef et al., 1976; Vallentyne, 1978; UNEP-IETC, 2001; Pelley, 2016; Qin et al., 2013; Azevedo et al., 2015; Beghelli et al., 2015; Vidović et al., 2015). Caused by excessive concentrations of nitrogen and phosphorus in the aquatic ecosystem, eutrophication can result in public health issues and ecological alterations including massive blooms of phytoplankton and cyanobacteria (Rast et al., 1989; Correll, 1998; Jiang et al., 2010).

Cyanobacteria are a major socioeconomic problem due to the release of toxins and taste-and-odor compounds into lakes, reservoirs, and rivers, leading to significant economic and public health issues, especially where water bodies are used for drinking water supply, recreational purposes, and/or cultural and socioeconomic services (Graham et al., 2008). Due to the significant impacts of harmful algal and bacterial blooms (including cyanobacteria, thermotolerant coliforms, and other pathogenic bacteria), these phenomena require the adoption of direct control or mitigation measures (Thornton et al., 1996; Raloff, 2002; Beaulieu et al., 2005).

The occurrence of cyanobacterial blooms constrains the recreational use and socioeconomic potential of many water bodies in countries of all continents across the globe (Codd et al., 2005). These last authors denoted that several countries over the world have or still are suffering from the eutrophication: a) in South Africa, the eutrophication has severe impacts on health, society, and the economy; b) Netherlands and Norway have experienced increasing loss of recreational water use during the summer months, due to eutrophication; c) in Europe and Oceania there have been other temporary closures of water bodies for recreational activities, with consequent losses in terms of amenity and the local economy, despite the monitoring of cyanobacteria populations and cyanotoxins, and the implementation of recreational safety guidelines and procedures.

In order to control and/or mitigate water resources eutrophication, several countries have produced limnological guidelines, management protocols, and environmental quality reports, which vary in terms of the type of action, the environmental issues assessed, and the management procedures adopted (Macdonald et al., 2000). A few countries (such as Brazil) have implemented water management policies based on microcystin concentrations in the water body (Codd et al., 2005; Brasil, 2011).

In some countries (especially the developed ones), the use of copper sulfate $\left(\mathrm{CuSO}_{4} \cdot 5 \mathrm{H}_{2} \mathrm{O}\right)$ as an algicide was abolished a long time ago (Codd et al., 2005). However, in Brazil, it is still one of the commonest methods used to control cyanobacteria. In the case of the Guarapiranga reservoir in São Paulo state, massive amounts of copper sulfate have been used since 1979 (Mancuso, 1987), with the reservoir sometimes receiving 350 tons of copper sulfate in only one year (CETESB, 2009). Nonetheless, there has been no evidence of improvement in the water quality of this reservoir (CETESB, 2013).

The use of copper sulfate to prevent algal growth and "clean" the water body has led to several intoxications of livestock due to the release of cyanobacterial toxins through membrane cell rupture (Yoo et al., 1995). A case of severe intoxication of humans has also been reported after treatment of water used for human consumption with copper sulfate (Byth, 1980; Bourke et al., 1983). Elsewhere, a massive fish kill of $>6$ tons occurred after treatment of an algal bloom with copper sulfate in Kezar Lake, New Hampshire, USA (Sawyer et al., 1968). In Nova Scotian lakes, there have been observed effective local fish, plankton and bottom fauna kill due to copper sulfate application (Smith, 1939).

According to SMITH (1939), copper sulfate is toxic to diatoms, dinoflagellates, chlorophytes, and cyanobacteria. Copper sulfate inhibits photosynthesis and cell division, hinders nitrogen and phosphorus uptake, reduces the photosynthetic pigments in the cells, affects plasma membrane permeability, deceases cell motility, alters the distributions of proteins, lipids, and fatty acids within the cells, and even results in membrane cell rupture (Wehr and Sheath, 2003).

Copper sulfate application is considered a risky water management method compared to other alternatives, once: a) it causes membrane cell rupture, and specifically for the case of cyanobacteria, it enhances the cyanotoxines release into the water (EPA, 2014, 2016); b) it is potentially toxic to humans both in ion $\left(\mathrm{Cu}^{2+}\right)$ and full molecule states $\left(\mathrm{CuSO}_{4}\right)$ (Holtzman et al., 1966; Singh and Singh, 1968; Krieger, 2001; Saravu et al., 2007; Sinkovic et al., 2008). Direct contact and exposure to copper sulfate in the air can lead to skin thickness increase and green coloration of the skin, teeth, and hair. In the respiratory system, chronic exposure leads to nasal inflammation, septum perforation, and ulceration. Copper may cause hepatotoxicity, and loss of fertility has been observed in laboratory animals (Pedrozo, 2003). In adults, emetic copper sulfate dosages range from 0.25 to $0.5 \mathrm{~g}$ (as $\mathrm{Cu}$ ). Intake of water or food containing $25 \mathrm{mg}_{(\mathrm{Cu})} / \mathrm{L}$ has been reported to cause acute gastroenteritis, while a dose of $250 \mathrm{mg}(\mathrm{Cu}) / \mathrm{kg} /$ day can lead to hepatic necrosis in higher animals (Barceloux, 1999). Repeated oral doses of copper sulfate were found to affect the liver, stomach, and kidneys in rats (Bartram et al., 1999).

Fortunately, copper sulfate tends to precipitate in limnological environments, becoming fixed in the sediment (John and Leventhal, 1995; Smith, 2007; Nordstrom et al., 1999; Beghelli et al., 2015; CETESB, 2012, 2013, 2015). Nevertheless, even low levels of copper sulfate or ionic copper can be lethal to fish and microorganisms, which are highly sensitive to the metal, with mortality of microorganisms at levels typically around $1.0 \mathrm{mg} / \mathrm{L}$, while trout, carp, catfish, and ornamental goldfish present mortality at copper concentrations of around $0.5 \mathrm{mg} / \mathrm{L}$ (CETESB, 2003). Nonetheless, reports as Korosi and Smol (2012) denote that copper sulfate not only alters the aquatic food webs, but it also imposes a resilience to the system, inhibiting the ecosystem to recover to its previews state prior to the algicide applications.

Several factors affect the toxicity of dissolved copper in water. Copper toxicity decreases with increasing water hardness, due to the competition between calcium and copper for absorption sites on biological surfaces (WHO, 1998). Under certain conditions of $\mathrm{pH}$ and carbonate concentration, most of the aqueous copper $\mathrm{Cu}$ (II) becomes complexed, reducing its reactivity (WHO, 1998; Barceloux, 1999). Only a small portion of the copper remains in the aqueous state, while another portion is adsorbed by suspended particles or is complexed by carbonates and hydroxides. In aqueous environments such as reservoirs and lakes, the largest portion of the copper remains attached to organic compounds including humic and fulvic acids (Pedrozo, 2003), which can hinder the evaluation of potential ecotoxicological effects.

Despite the ecotoxicological and human health implications of copper sulfate, it offers an easy and relatively inexpensive technique for water body management, producing a rapid environmental response (Padovesi-Fonseca and Philomeno, 2004; Kansole and Lin, 2017). Nevertheless, the use of copper sulfate is not the only option for water quality management (Beaulieu et al., 2005; Huh and Ahn, 2017). Other effective methods for the control of algae and cyanobacteria include the use of hydrogen peroxide, which is associated with fewer longterm ecotoxicological impacts (Matthijs et al., 2012; Bauzá et al., 2014; Lürling et al., 2014).

The São Paulo State agency responsible for basic sanitation (SABESP) has used hydrogen peroxide for algal control, obtaining strong and positive environmental responses (Caleffi, 2000; CETESB, 2008; SABESP, 2011b). Many other possible techniques avoid the use of algicides: flushing, destratification, hypolimnetic aeration, epilimnetic mixing, metalimnetic mixing, and layer aeration are just some of these other options available (Straškraba and Tundisi, 1999).

One specific type of eutrophication prevention method for water bodies is full sewage collection and treatment (Hassler, 1969; Golterman et al., 1983). Since the sewage is fully treated, passing through tertiary and in some cases quaternary processes, the residual phosphorus and nitrogen level is minimal, compared to in natura 
sewage. This strategy can be short term expensive (Wood et al., 2015), although the results are direct and effective in the long term, and it can also mitigate other potential health issues, hence providing cost savings.

Given the substantial socioeconomic and ecological impacts due to copper resuspension and dissolution at the Guarapiranga reservoir, there is a need to develop effective strategies for the management of this water body, considering the risks associated with continuous algicide applications. In turn, this requires efficient environmental evaluation. Although a variety of techniques can be used for classification of water quality, a common difficulty relates to the spatial heterogeneity of water resources. Single-site and local ecotoxicological evaluations are widely reported, but the interpretation of large-scale spatial variability has received less attention. A growing scientific area, which focuses precisely on this issue, is landscape ecotoxicology (Cairns and Niederlehner, 1996; Focks, 2014). Despite still being an emerging scientific area, certain methodological approaches have been developed that help to overcome the difficulties associated with spatially-resolved ecotoxicological evaluations.

This work describes a landscape ecotoxicology approach designed to assist in the assessment of Brazilian water management procedures and policies. The specific objectives were as follows: a) Development of a method to evaluate current levels of copper and its horizontal heterogeneity in surficial sediments of Brazilian reservoirs, employing the Guarapiranga reservoir as a model environment; b) Qualitative evaluation of the condition of this environment after a long period of copper sulfate application, using the Water Framework Directive approach (Contaminated Sediment Standing Team, 2003; Macdonald et al., $2000)$; c) Identification of potential hazardous ecotoxicological scenarios for this reservoir; d) Evaluation of an alternative treatment process for this reservoir.

Since the eutrophication of water sources is still a problem worldwide, and the use of copper sulfate for its management is a common procedure, an overall aim of this work is to discuss the management policies adopted for tropical reservoirs and their ecotoxicological implications. We hypothesize that: (i) Copper sulfate application is inefficient and expensive in the long term, while management strategies such as sewage treatment plant (STP) implementation, sewage network construction (SNC), and full sewage system installation provide cheaper solutions; (ii) Copper sulfate application imposes much greater ecotoxicological pressure on the environment, compared to the sewage treatment option.

In order to address hypothesis (i), we estimated operational costs based on recent official reports and scientific publications. For hypothesis (ii), we developed and applied a landscape ecotoxicological model inserted in a geographic information system (GIS) based on the Water Framework Directive and Regional Reference Value concepts. In order to implement the landscape ecotoxicological model, empirical field data were acquired for the surficial sediment of a Brazilian tropical reservoir (the Guarapiranga reservoir) that has experienced long-term copper sulfate application (over 40 years). The surficial sediment was selected for implementation of the landscape ecotoxicological model for two main reasons. Firstly, the sediment compartment accumulates metals to a much greater extent than the water column, sometimes acting as a pollutant sink and at other times as a source of contaminants (Silva, 2013b; Förstner and Wittmann, 1981; Shafie et al., 2013). Therefore, the sediment presents a significant ecotoxicological risk, since contaminants can become bioavailable to the ecosystem (von der Ohe et al., 2009; Silva, 2008). Secondly, the sediment provides a better spatiallyresolved record of possible historical contamination events in reservoirs (Varol and Şen, 2012), hence facilitating estimates of operational costs.

\section{Study area}

The Guarapiranga reservoir is located in a sub-basin of the Alto Tietê in São Paulo State, Brazil (Fig. 1). Its mean coordinates are $23^{\circ} 43^{\prime} \mathrm{S}$ and $46^{\circ} 32^{\prime} \mathrm{W}$ (WGS-84). It is under a tropical climate and is nearly $742 \mathrm{~m}$ above sea level. Its maximum volume is $194 \times 10^{6} \mathrm{~m}^{3}$ (Melchor et al., 1975 ) and it covers an area of $34 \mathrm{~km}^{2}$ (Silva, 2008).

Maier (1985) describes the Guarapiranga as being a polymictic reservoir. Its retention time ranges between 110 and 143 days (CETESB, 1992, Beyruth, 1996) and its outflow is around $14 \mathrm{~m}^{3} / \mathrm{s}$ (SABESP, 2014). It has maximum and mean depths of 13 and $6 \mathrm{~m}$, respectively (Kleerekoper, 1939; Maier and Takino, 1985), so it is therefore described as a small reservoir (Straškraba and TUNDISI, 2000).

The Guarapiranga reservoir began operating in 1908, with damming of the Guarapiranga River for electricity generation (Emae, 2007). Since 1928 , this reservoir has been an important source of water supplied to the São Paulo metropolitan region (known as the RMSP).

In the 1960s, with increasing water demand by the RMSP, the Capivari river was diverted to the Embu-Guaçu river, one of the main tributaries of the Guarapiranga reservoir, enhancing the water supply to the RMSP by a further $1000 \mathrm{~L} / \mathrm{s}$ (Whately and Cunha, 2005). In 2000, another diversion was required in order to supply the RMSP's water needs. Therefore, the Taquacetuba branch of the Billings complex was diverted to the Parelheiros river, finally discharging into the Guarapiranga reservoir. This new water diversion enhanced the outflow by another $2000-4000 \mathrm{~L} / \mathrm{s}$.

Although the Guarapiranga is considered a shallow reservoir and is smaller than the world's 50 largest reservoirs by volume (Sperling, 1999), it now produces around 14,000 L/s of water, supplying nearly 3.7 million inhabitants (approximately $20 \%$ of the RMSP population) (Whately and Cunha, 2005).

The Guarapiranga basin is used for many anthropic purposes, including sand and kaolin mining, aquatic sports, and agriculture, with industrial installations in the eastern, northern, and northwestern sub-basins (Pompêo et al., 2013; Queiroz, 2014; Schunk, 2013). In the west, the basin is dominated by unauthorized housing (favelas) and a small park (Parque do Guarapiranga), with significant vegetation coverage (Eiger et al., 2012).

The water quality of the Guarapiranga has steadily worsened since 1970 , due to the effects of sewage and diffuse pollution discharges in the basin (Whately and Cunha, 2005). In the early 1980s, algal blooms became an important issue affecting water treatment and energy production (due to clogging of the turbines of the hydroelectric plant) (Beyruth, 1996). Since then, the Guarapiranga has remained eutrophic (Caleffi, 2000), and since 1976 copper sulfate has been the main resource used to control algal blooms (Caleffi, 2000). Zagatto (1995) reported that copper sulfate was applied on an almost daily basis $(\approx 4$ ton/day), and only recently has copper sulfate been substituted by hydrogen peroxide as the main management procedure for control of the algal blooms, especially in relation to cyanobacteria blooms (Caleffi, 2000; CETESB, 2008).

\section{Materials and methods}

\subsection{Landscape delimitation (reservoir margin) and bathymetric data}

In order to assess the surficial sediment of the Guarapiranga reservoir, the recent bottom sediment was first delimited, followed by generation of a digital elevation model (DEM) of the bottom terrain of the reservoir.

The first procedure involved delimiting the free water surface of the reservoir, ignoring surface algal patches, inlets, and sandbanks. The sediment surface was considered as the landscape with ecotoxicological relevance, or ecotoxicologial landscape unit (ELU). The ecotoxicological landscape concept has been applied elsewhere, but without proper definition (Cairns and Niederlehner, 1996; Feist et al., 2011; Souza and Wasserman, 2015).

In the ELU approach, the spatial definition of the sediment sampling points must be coherent with ecotoxicological concepts, in order to satisfy two basic ecotoxicological conditions: a) avoidance of using 


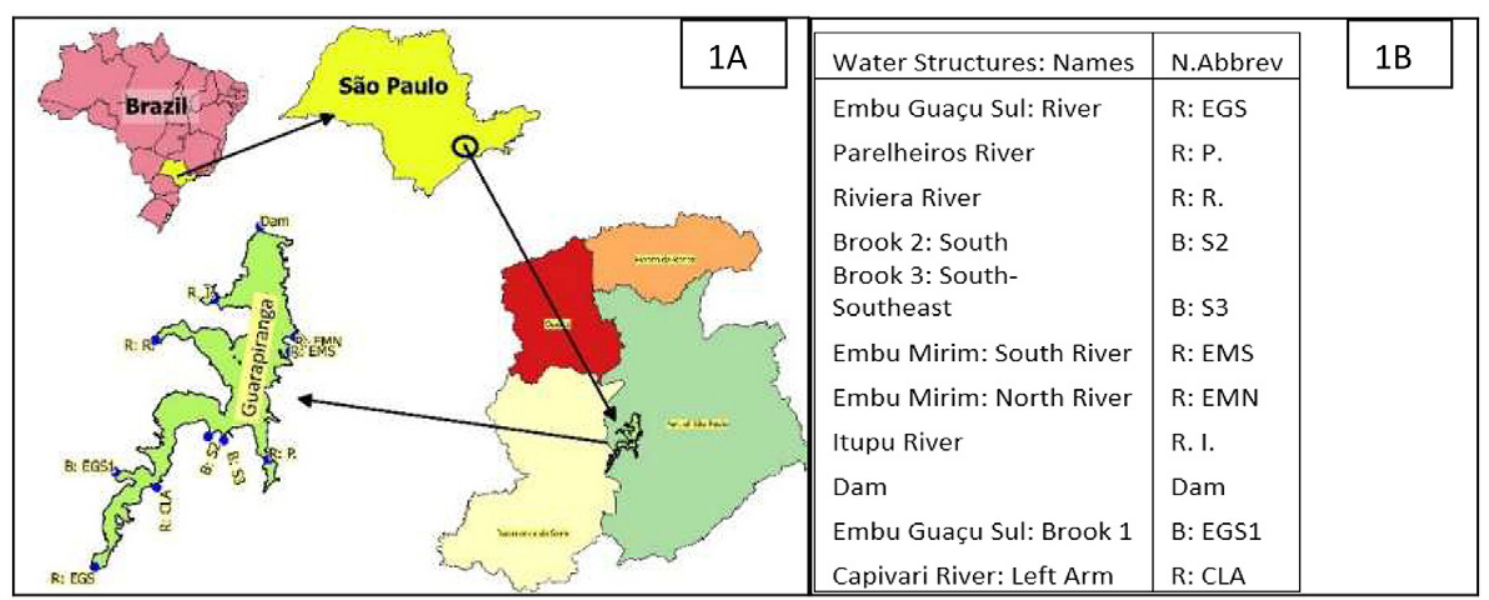

Fig. 1. A) Study Area (Reservoir Guarapiranga - São Paulo, Brazil); B) Reservoir Guarapiranga's tributaries and respective abbreviations.

recently exposed soil/sediment that has experienced interrupted contact with the aquatic biota and could interfere in the spatial analysis; b) avoidance of using sediment recently exposed to air, resulting in oxidation, water loss, and altered ecotoxicological effects in the biota (Vaz, 1996; Melo et al., 2006). Sediment and bathymetric sampling should therefore be restricted to those areas where sediment has been fully and continuously connected to the water column, excluding shallow or near-shore locations. In the present case, the study focused only on the sedim|ent that satisfied these ecotoxicological conditions.

In order to ensure that both of the above conditions were satisfied, the sediment sampling design and delimitation of the ELU margins had to be strictly structured. The margins delimited the ecotoxicological effects on the local limnological biota caused by the contaminated sediment. As the reservoir margin was extensive, with a strongly dendritic form, it was obtained by visual vectorization based on the ALOS satellite georeferenced image for 9th March 2010, when the water level of the reservoir was at $735.64 \mathrm{~m}$ above sea level. The ALOS spatial definition is almost $10 \mathrm{~m}^{2}$, which was considered sufficient for the visual vectorization of the reservoir margin, and the satellite image was georeferenced using a subsample of the bathymetric data points.

Visual vectorization was selected because the Guarapiranga reservoir is shallow and is extensively covered by surface macrophytes (Lage, 2013), hindering automatic classification and spatial vectorization methods (Dekker et al., 2005; Fornes et al., 2006; Su et al., 2014).

The bathymetric sampling was performed on 29th and 30th July 2015, using a zigzag track that enabled better assessment of the entire reservoir (Fig. 2A). The data were collected with a Garmin Fishfinder GPSmap 421S instrument attached to a datalogger and were georeferenced using the

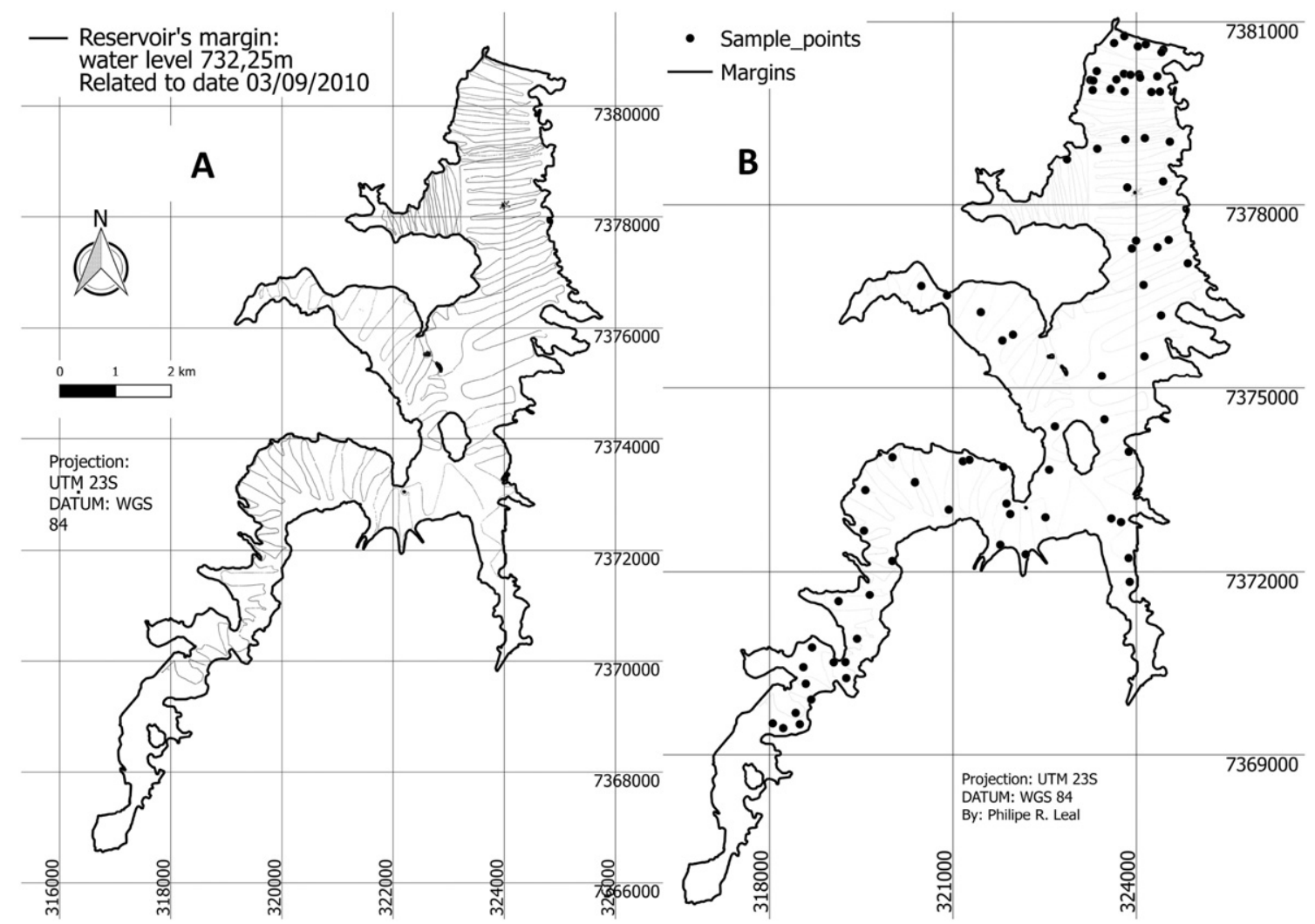

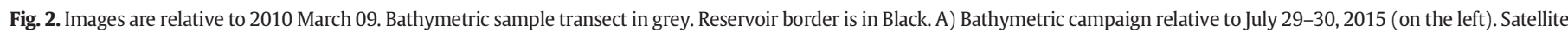
ALOS; and B) Sediment sampling points (on the right). 
WGS-84 datum with the UTM 23S projection. This bathymetric sampling method followed the procedures described previously (Danton and Bilhalva, 2013; Resck et al., 2007), maintaining a mean vessel speed of $17 \mathrm{~km} / \mathrm{h}$ in order to reduce misreading due to water turbulence. The Fishfinder bathymetric probe was selected due to its low cost, easy installation and operation, and ability to acquire large quantities of data (Danton and Bilhalva, 2013).

Subsequently, the bathymetric and margin data were used for modeling the reservoir bottom and the copper levels. This modeling required a bathymetric standardization in order to improve comparison with data for other reservoirs and environments, with conversion of the bathymetric data to altimetric data using Eq. (1). This equation requires knowledge of the reservoir water level on the day of acquisition of the satellite data, together with the bathymetric data. The water level on 9th March 2010 was 735.64 m (Empresa Metropolitana de Águas e Energia S.A. - EMAE).

Altimetry $_{(\mathrm{i})}=R W_{(\mathrm{j})}$-Depth sampled (from point $\mathrm{i}$ )

\section{Altimetry $_{(\mathrm{i})}$ : Altimetry of point (i)}

$R W C_{(\mathrm{j})}$ : Reservoir water level for day $(\mathrm{j})$

Depth of point (i): Point (i) of projected UTM coordinates (X and Y)

The next step was the construction of the digital elevation model (DEM) derived from the interpolation of the 22,165 bathymetric points. The triangulated irregular network (TIN) model based on the Delaunay criterion (empty circumcircle principle), where the circle circumscribing any triangle contains no other data points except the three defining it, was identified as the most suitable interpolator for the task. This method ensures use of the observed minima and maxima in bathymetric field surveys and is highly effective for dense and well-gridded samples, enabling easy incorporation of discontinuities and structural features of the landscape. It is easy to interpret, is well established as a common interpolator in SIG software packages, and permits dynamic visualization analyses (Mitas and Mitasova, 1999; Sárközy, 1998; Sutton et al., 2009).

After the DEM map had been generated, the Sextant QGIS extension was used to obtain the first order partial derivation maps for the north-south (dY) and east-west (dX) directions, as described by Sá (2014). This allowed the acquisition of the partial slopes (dY and dX) for each cell of the matrix (the Guarapiranga reservoir sediment surface). Employing the criteria described by Horn (1981), a script was used in the calculator field of the QGIS software, considering the cosine of each partial first order derivation. As the DEM map projection kept the original formatting (UTM 23-S), with meters as distance units, this script allowed the computer to calculate the real surface area of each cell of the matrix, resulting in the RSS map.
The general equation for obtaining the real surface area is shown below (Eq. (2)), extracted from Horn (1981).

$\mathrm{RSS}=\left[\mathrm{X}_{(\mathrm{i})} / \operatorname{cosine}(\mathrm{dx})\right] *\left[\mathrm{Y}_{(\mathrm{i})} / \operatorname{cosine}(\mathrm{dy})\right]$

$\mathrm{X}$ : Cell east-west axis dimension: ALOS satellite $\mathrm{X}_{(\mathrm{i})}$ definition $=$ $10 \mathrm{~m}$

Y: Cell north-south axis dimension: ALOS satellite $\mathrm{Y}_{(\mathrm{i})}$ definition $=$ $10 \mathrm{~m}$

In the next step, the QGIS spatial analysis procedure was applied, which overlaps shape and matrix layers in order to calculate the total sum, standard deviation, number of cells, and maximum and minimum values of the matrix map, summarized in the shapefile. These values were then transferred to Excel v. 2013 software for further statistical analysis and graph generation.

\subsection{Sediment sample and copper concentration assessments}

The surficial sediment was designated as the system component of ecotoxicological interest for this research, for two main reasons. Firstly, this compartment accumulates metals to a much greater extent than the water column (Silva, 2013b; Förstner and Wittmann, 1981; Shafie et al., 2013), resulting in a greater ecotoxicologial threat, should a toxic metal become bioavailable to the ecosystem (von der Ohe et al., 2009; Silva, 2008). Secondly, the sediment provides a better historical record of previous contamination events and their spatial patter (Varol and Şen, 2012).

The sediment field data acquisition was performed on a single day (6th May 2015), hence minimizing possible internal variations in the reservoir (Golterman et al., 1983; Ford, 1990; Thornton et al., 1996; Esteves, 1998). The sampling points were distributed throughout the ELU of the reservoir in order to better assess the spatial variation. Each sediment sampling point was georeferenced (WGS-84 with UTM 23S) for later insertion in the GIS environment.

The sediment was collected with a $400 \mathrm{~cm}^{2}$ Lenz type sampler (Carvalho, 1994). Assessment was made of the first $4 \mathrm{~cm}$ of the surficial sediment, corresponding to the past 11 years of copper sulfate application (Silva, 2013a; Campagnoli, 2002). The sediment samples were preserved in a cold and dark environment until analyzed. The sampling design followed the procedure of Schropp et al. (1990).

In the laboratory, the sediment samples were dried to constant weight at $50{ }^{\circ} \mathrm{C}$ and were then powdered using a glass mortar and pestle. Copper concentrations were determined using the USEPA pseudototal sediment digestion Method 3050B (USEPA, 1996). The analyses were performed using a flame atomic absorption spectrometer (Thermo Scientific, S Series, AA).

Table 1

Sediment qualitative coloring rules for RGB system.

\begin{tabular}{l|l|l} 
IES: Classes & \multicolumn{1}{|c|}{ Limites/Intervalos } & \multicolumn{1}{c}{ Potencial Ecotox. } \\
\hline Excellent & $0 \mu \mathrm{g} / \mathrm{Kg}_{(\text {sedimento seco })} \leq[\mathrm{M}]<$ VRR & Region with minimal ecotox. potential. Basal Concentrations \\
\hline Good & VRR $\leq[\mathrm{M}]<\mathrm{ISQL}$ & $\begin{array}{l}\text { Region with possible anthropic contamination, but with little to improbable } \\
\text { ecotox. activity }\end{array}$ \\
\hline Regular & $\mathrm{ISQL} \leq[\mathrm{M}]<\mathrm{PEL}$ & $\begin{array}{l}\text { Region with anthropogenic contamination, of unknown ecotox. activity, and } \\
\text { medium occurrence probability }\end{array}$ \\
\hline Bad & $\mathrm{PEL} \leq[\mathrm{M}]<10^{*} \mathrm{PEL}$ & Region with high ecotox. activity, and high occurrence probability \\
\hline Terrible & $10 * \mathrm{PEL} \leq[\mathrm{M}]<+\infty$ & Region with maximum ecotox effect, and maximum occurrence probability. \\
\hline
\end{tabular}




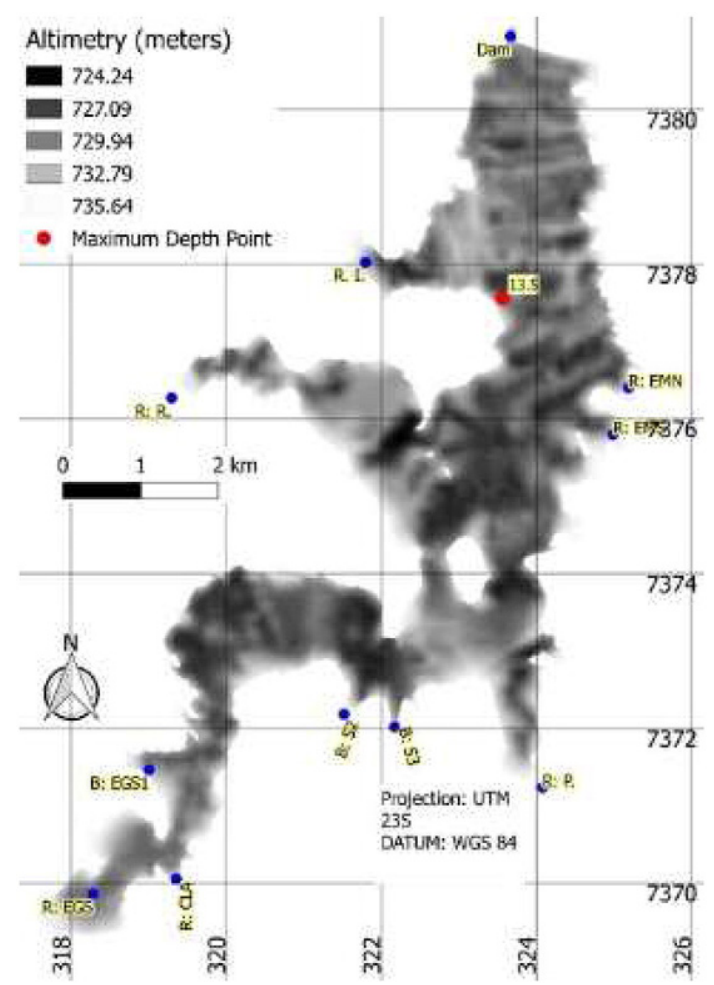

Fig. 3. Altimetric map. Maximum Depth point: red dot. Affluent in blue dots (names and abbreviations in Fig.1A).

\subsection{Copper spatial interpolation and spatial analysis}

In order to understand the spatial distribution of copper throughout the Guarapiranga ELU, a kriging interpolation method was implemented using Geovisual v. 5.0 software, following the procedure of Yamamoto and Landim (2015). This technique has been used in other similar studies (Smal, 2015; Batista, 2011; Alcantara, 2008; Burgos-León et al., 2012), and it has been shown to be an excellent tool for spatial analysis (Cressie, 1993; Camargo et al., 1999, 2001; Machado et al., 2004).

\subsection{Copper stock assessment}

For assessment of the copper stock for the entire ELU, the mean copper concentration extracted from the kriging interpolation method ([Cu])as used in Eq. (3), enabling evaluation of the amount of copper present in the surficial sediment of the Guarapiranga reservoir $\left(\right.$ Stock $\left._{(\mathrm{Cu})}\right)$.

Stock : $\left[\left(\frac{\mathrm{FS}}{\mathrm{Kv}} * \mathrm{SRS} * h\right)-(\mathrm{Wm})\right] *[\mathrm{Cu}] * 10^{-3}$

FS: Fresh sediment mass (kg)

$h$ Mean penetration of the Petersen sediment sampler ( $\mathrm{m}$ )

[Cu] Mean copper concentration for the entire reservoir, extracted from the copper kriging $\left(\mathrm{kg}_{\text {(copper) }} / \mathrm{kg}_{\text {(dry weight) }}\right)$

$\mathrm{kv}=$ Constant volume $\left(1.2 * 10^{-4} \mathrm{~m}^{3}\right.$ of fresh sediment $)$

RSS: Real sediment surface ( $\mathrm{m}^{2}$ of fresh sediment)

Wm: Mean water mass present in the sediment samples $(\mathrm{kg}$ of water)

MMCSS: Copper stock (ton of copper)

\subsection{Qualitative copper concentration analysis}

The next step was to qualitatively evaluate the condition of the reservoir sediment. This evaluation employed the following sediment quality guidelines (SQGs): a) the Water Framework Directive (WFD), the interim sediment quality guidelines (ISQGs) and the probable effect levels (PELs) (Canadian Council of Ministers of the Environment, 1999; USEPA, 2005); and b) the regional reference value (RRV) of the Bacia do Alto Tietê (NASCIMENTO, 2003).

The first approach (WFD) allowed the classification of the reservoir in portions according to the associated potential ecotoxicological risk. The RRV approach enabled evaluation of the impacts of anthropogenic activities. The SQGs are linearly structured in order to provide a classification index capable of delimiting the different zones of a reservoir according to their effective ecotoxicological potential. This index considers five distinct classes, following the criteria of Cardoso-Silva (2013b) (Table 1).

Table 2

Guarapiranga's morphometric parameters.

\begin{tabular}{|c|c|c|c|c|c|c|c|c|}
\hline Nome & $\begin{array}{l}\text { This } \\
\text { research }^{\mathrm{a}}\end{array}$ & $\begin{array}{l}\text { Nishimura } \\
\text { (2012) }\end{array}$ & Mozeto et al. (2001) & $\mathrm{EMAE}^{\mathrm{b}}$ & $\begin{array}{l}\text { Oliveira et al. } \\
\text { (2013) }\end{array}$ & $\begin{array}{l}\text { Andrade et al. } \\
(2013)\end{array}$ & CETESB (2002) & $\begin{array}{l}\text { Kleerekoper } \\
\text { (1939) }\end{array}$ \\
\hline Total planar area $\left(\mathrm{km}^{2}\right)$ & 24.85 & $34^{\mathrm{d}}$ & - & $33.91^{\mathrm{j}}$ & 26.63 & $27.78^{1}$ & $33^{\mathrm{j}}$ & $35^{\mathrm{j}}$ \\
\hline Sediment surface area $\left(\mathrm{km}^{2}\right)$ & 29.71 & - & - & & & & & \\
\hline Perimeter $(\mathrm{km})$ & 93.268 & $85^{d}$ & - & - & & & & \\
\hline Total planar basin area $\left(\mathrm{km}^{2}\right)$ & - & $639^{e}$ & - & 631 & & 636.96 & & \\
\hline Maximum depth (meters) & 13.5 & & & & & & & 13 \\
\hline Mean depth (meters) & 5.72 & $7^{\mathrm{f}}$ & - & $5.83^{\mathrm{j}}$ & & & $7^{\mathrm{j}}$ & 5.7 \\
\hline Ratio area/perimeter & 0.266 & 0.4 & - & - & & & & \\
\hline Working volume $\left(\mathrm{hm}^{3}\right)$ & $160.09^{\mathrm{g}}$ & - & $191.6^{\mathrm{c}}$ & $191.6^{\mathrm{k}}$ & & & $194^{\mathrm{i}}$ & \\
\hline Maximo maximorum volume & & & & $197.6^{\mathrm{h}}$ & & & & \\
\hline
\end{tabular}

a Water level (altimetry value) of $735.64 \mathrm{~m}$ (based on the ALOS satellite imagery data - 09/03/2010).

b EMAE - Empresa Metropolitana de Águas e Energia S.A.

c Water level unknown.

d (CETESB, 1991, apud Nishimura, 2012).

e (Whately and Cunha, 2006, apud Nishimura, 2012).

f (CETESB, 2002, apud Nishimura, 2012).

$\mathrm{g}$ Volume derived from the trapezoid equation for a $732.25 \mathrm{~m}$ water level.

$\mathrm{h}$ Maximum maximorum $=737.60 \mathrm{~m}$ (altimetry of the water level).

${ }^{i}$ No water level indication by the author.

${ }^{\mathrm{j}}$ No description of the type of area (real or planar), water level or the volume equation adopted in the article.

k Appliable water storage level - water level of $736.62 \mathrm{~m}$.

${ }^{1}$ Water level of $734.98 \mathrm{~m}$. 

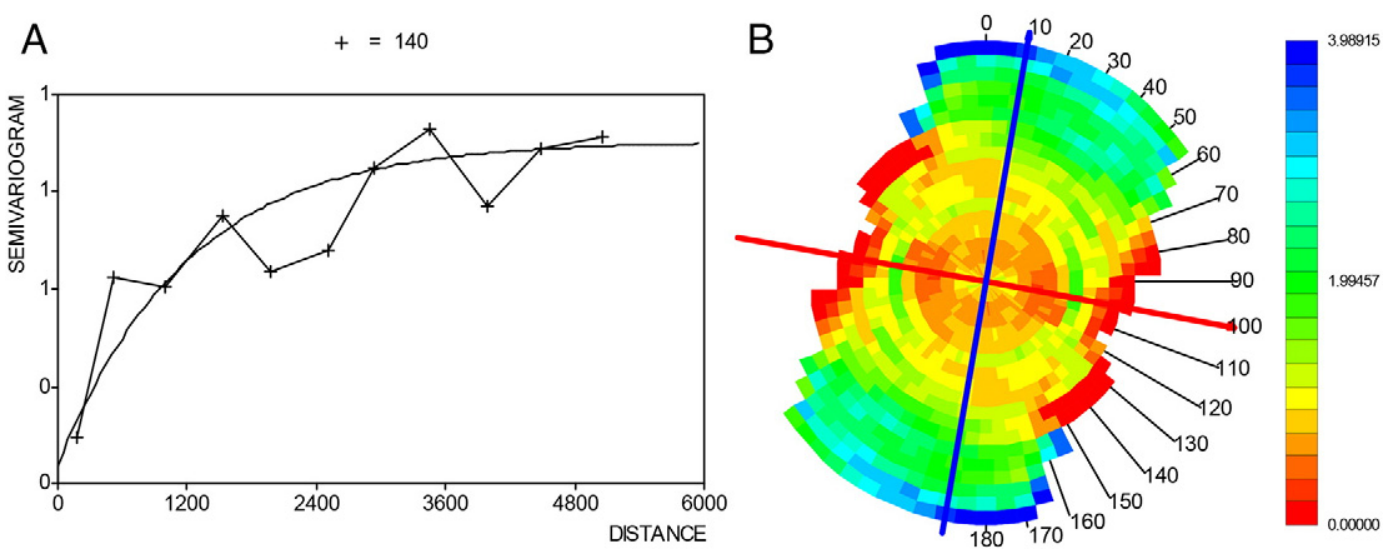

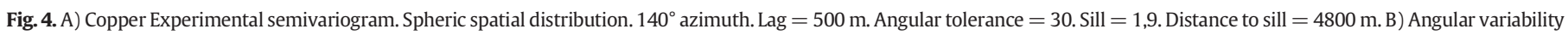
graph. Blue and red axis represents the azimuthal axis of major and minor spatial variability respectively.

\section{Results and discussion}

\subsection{Bathymetric survey}

The bathymetric survey resulted in a total of 18,599 points (shown by the grey line in Fig. 2). The margin vectorization added a further 3488 points (black line in Fig. 2A). Bathymetric data were also acquired for the sediment sampling points (78 points) (Fig. 2B). Therefore, the modeling and interpolation of the sediment surface of the Guarapiranga reservoir employed a total of 22,165 reference points.

\subsection{Altimetry and morphometry}

After obtaining the altimetry map, analysis was made of the bathymetric pattern, especially considering the maximum and minimum depths. Disregarding the ELU margins ( $0 \mathrm{~m}$ deep), the bathymetric values varied from $0.5 \mathrm{~m}$ to $13.5 \mathrm{~m}$ at the deepest point (red dot in Fig. 3). The regions of greatest depth were in the central body of the reservoir, despite the general sedimentation pattern described by Sperling (1999).

The volumetric data for the reservoir, obtained using the Surfer v. 5.0 software, are shown in Table 2 . The other morphometric parameters were obtained using the Quantum GIS v. 2.14.1 software. Using the equation of the trapezoid, the reservoir volume was estimated to be $160.09 \mathrm{hm}^{3}$. Mozeto et al. (2001) and the Company "Empresa Metropolitana de Águas e Energia S.A.” - EMAE (no data) found significantly higher values, although no descriptions were provided of the bathymetric surveys, water levels, or methodological procedures adopted. In this reservoir, the sedimentation rate can greatly influence the volume (Campagnoli, 2002; Guimarães, 2011; Simões et al., 2012).

Table 3

Copper Kriging parameters and values.

\begin{tabular}{ll}
\hline Parameters & Kriging values \\
\cline { 2 - 2 }$\left[\begin{array}{ll}\mathrm{Cu}]: \mathrm{g}_{\text {(Copper) }} / \mathrm{kg}_{\text {(dry sediment) }} \\
\hline \text { Median }\end{array}\right.$ & 1,11 \\
Global standard deviation & 1.147 \\
Minimal median deviation & 0.399 \\
Maximum median deviation & 1.227 \\
Minimal concentration & 0.002 \\
Maximum concentration & 2.952 \\
Azimuth & $225^{\circ}$ \\
Sample effort & 78 sites \\
Kriging grid size & $195 \times 195 \mathrm{~m}$ \\
\hline
\end{tabular}

The RSS of the Guarapiranga reservoir was estimated to be $29.71 \mathrm{~km}^{2}$, which was lower than found in previous decades, due to shrinking of the margins as a result of sediment clogging (Campagnoli, 2002; Silva, 2005).

\subsection{Sediment copper evaluation}

\subsubsection{Quantitative copper status}

Fig. 4A presents the experimental semivariogram for copper in the Guarapiranga sediment, structured on a spherical distribution basis. The results showed substantial spatial correlation, with a strong sill and primary and secondary stationarity, as described by Yamamoto and Landim (2015). The semivariogram presented a large relative

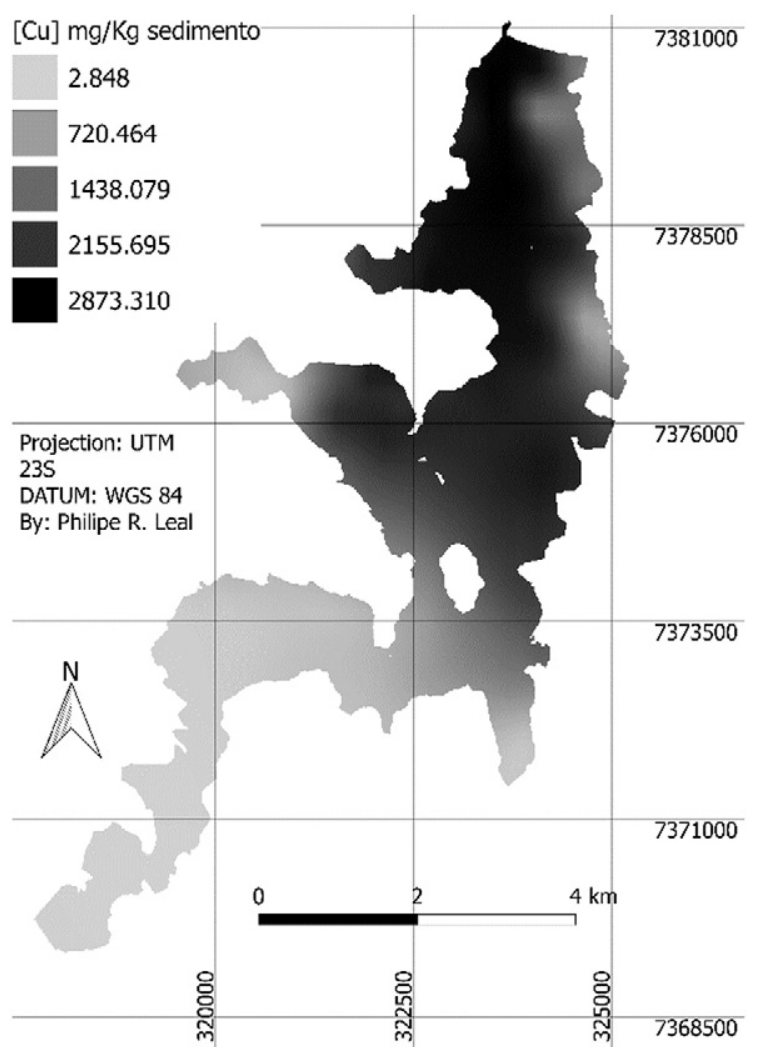

Fig. 5. Graphical representation of spatial copper concentration in the Guarapiranga's Reservoir sediment. 
Table 4

Comparison of copper concentration in different Brazilian reservoirs - units in $\mathrm{mg} / \mathrm{kg}_{\text {(dry sediment). }}$.

\begin{tabular}{|c|c|c|c|c|c|c|c|}
\hline References & Reservoir & Minimum & Maximum & Sample mean & Sample SD & Krig mean & Krig SD \\
\hline This research (samples from 2015) & Guarapiranga $^{a}$ & 0 & 3011.99 & 1241.64 & 1135.62 & 1111.00 & 1146.67 \\
\hline Pompêo et al. (2013) & Guarapiranga $^{a}$ & 29.2 & 2902.4 & 1157.2 & 1125.6 & - & - \\
\hline Padial (2008) - 5/10/2006 & Guarapiranga $^{a}$ & 27.55 & 2970.8 & 1157.23 & 1014.50 & - & - \\
\hline Padial (2008) - 27/04/2007 & Guarapiranga $^{a}$ & 64.18 & 3154.06 & 1089.70 & 894.82 & - & - \\
\hline Rosa et al. (capítulo 15. 2015) & Itupararanga ${ }^{\mathrm{b}}$ & 4 & 28.8 & 14.56 & 6.78 & - & - \\
\hline Mariani; Pompêo, (2008) & Braço Rio Grande ${ }^{a}$ & 8.2 & 3582.6 & 1644.1 & 1067.9 & - & - \\
\hline Bonai et al. (2009) & Itác & 151.6 & 233.95 & 179.86 & 22.61 & - & - \\
\hline Silva (2013b) & Paiva Castro $^{\mathrm{a}}$ & 4.35 & 109.98 & 77.20 & 35.08 & - & - \\
\hline
\end{tabular}

SD: Mean Standard Deviation.

Sample mean and SD: the Mean Standard Deviation and the mean concentrations obtained by the sample efforts.

Krig mean and SD: the Mean and the Mean Standard Deviation concentrations obtained by the kriging effort.

${ }^{a}$ Reservoir with copper sulfate application (Pompêo et al., 2015).

b Reservoir of reference (no apparent copper sulfate application) - (SILVA, 2012; Pompêo et al., 2015).

c Reservoir with severe pig and poultry farming activities, but no copper sulfate application (BONAI et al., 2009).

nugget effect ( $\mathrm{RNE}=\mathrm{C}_{\mathrm{o}} /$ Sill) of 0.029 (Tong et al., 2015), indicative of low spatial variability (Dasselaar et al., 1999). It can also be seen (Fig. 4B) that the copper presented isotropy. This was surprising, since the metal was derived from a diffuse source and was also liable to resuspension and dissolution (Pompêo et al., 2015).

The existence of copper resuspension and dissolution, as in the case of the Guarapiranga reservoir, can lead to impacts on both the ecosystem and human society (USEPA, 2016). Therefore, considering the amounts of copper present in the Guarapiranga and other Brazilian reservoirs with similar management practices, current policies are likely to result in problems of contamination and difficulty in water treatment.

The kriging interpolation resulted in the values shown in Table 3. The median values were subsequently used to estimate the copper stock. Fig. 5 shows the copper distribution throughout the ELU, with the highest copper concentrations located closer to the dam (northwards). The meridional portion of the reservoir also presented high copper concentrations in the sediment. The areas of lowest copper concentration were located southwards, distant from the dam. This copper spatial pattern was in general agreement with the results obtained by Pompêo et al. (2013). However, Pompêo et al. found a minimum copper concentration of $9.2 \mathrm{mg}$ (copper) $/ \mathrm{kg}_{\text {(dry sediment) }}$ in this reservoir, while the minimum copper concentration observed in the present work was at least 10-fold higher. Another difference was the location of the highest copper concentration. Pompêo et al. found that this region was closer to the dam, while in the present case it was in the central zone of the reservoir.

The differences described above lead to two hypotheses: a) the copper may not be totally fixed in the reservoir sediment and could therefore be liable to dissolution and dispersion throughout the water body, with subsequent sedimentation or incorporation in the food web; b) the copper present in the sediment may be resuspended back to the water column, undergo hydraulic transport through the reservoir, and potentially enter the water supply system, as observed in other reservoirs subject to the same algicide management practice (Hanson and Stefan, 1984). In either case, the situation is of major concern and requires further analysis.

Table 4 shows the evolution of the copper concentrations during the course of different studies of the same reservoir, from which it can be seen that the values have increased over the years, hence providing a further indication that the copper could represent a potential toxicological risk to humans.

The reference (minimum) copper concentration observed in the Guarapiranga reservoir sediment differed from the value reported by Nascimento (2003). This suggests that the copper carried in by the reservoir tributaries did not become strongly fixed in the upper regions of the reservoir basin and was therefore conveyed to the meridional region, where the lower hydrological forces allowed its deposition. This possibility should be investigated further in future studies.

Table 5 presents sediment copper concentrations for different water bodies under the same type of algicide management. In terms of the total amount of copper applied per unit area (tons of $\mathrm{Cu}$ per $\mathrm{km}^{2}$ ), the Guarapiranga reservoir has the third highest input, with the value only being lower than for the Hall and Buddy reservoirs due to its larger surface area. In terms of the total amount of copper applied per water body, the Guarapiranga reservoir showed the highest value. Its sediment copper concentration is now so high that it is comparable to levels in mining reject pools (Bai et al., 2011; Ashraf et al., 2012; Chen et al., 2013; Gharibreza et al., 2013).

Hanson and Stefan (1984) also found copper concentrations in water samples that suggested copper sulfate did not become strongly fixed in the sediment. The presence of copper was identified at different points of the water supply system, in waters of Monona lake, laboratory tap water, and the water distribution system, where the copper concentration was $0.02 \mathrm{mg} / \mathrm{L}$. These findings suggested that the water

Table 5

Copper sulfate application and copper in sediment concentration relationship for different water bodies with different periods of copper management.

\begin{tabular}{|c|c|c|c|c|c|c|c|c|c|}
\hline \multirow[t]{2}{*}{ Country } & \multirow[t]{2}{*}{ Water body } & \multicolumn{3}{|c|}{$\begin{array}{l}\text { Copper concentration in } \\
\text { sediments ( } \mathrm{mg} \mathrm{Cu} / \mathrm{kg} \\
\text { sediment) }\end{array}$} & \multirow[t]{2}{*}{ Surface area $\left(\mathrm{km}^{2}\right)$} & \multirow[t]{2}{*}{$\begin{array}{l}\text { Total copper applied } \\
\text { (tons of } \mathrm{Cu} / \mathrm{km}^{2} \text { ) }\end{array}$} & \multirow[t]{2}{*}{$\begin{array}{l}\text { Total years of } \\
\text { application }\end{array}$} & \multirow[t]{2}{*}{$\begin{array}{l}\text { Total copper applied } \\
\text { (ton } \mathrm{Cu} / \text { reservoir) }\end{array}$} & \multirow[t]{2}{*}{ Difference $(\log )$} \\
\hline & & Max & Min & Mean & & & & & \\
\hline BR & Guarapiranga & $3012^{b}$ & $0^{\mathrm{b}}$ & $1242^{\mathrm{b}}$ & $24.85^{\mathrm{b}}$ & $75.451^{b}$ & $43^{c}$ & $1874.98^{\mathrm{b}}$ & - \\
\hline USA & Hall $^{\mathrm{a}}$ & 1088 & 370 & 919 & 2.24 & 82.158 & 17 & 184.20 & 1.01 \\
\hline USA & Budd $^{a}$ & 1593 & 93 & 943 & 0.90 & 164.876 & 17 & 148.16 & 1.10 \\
\hline USA & Sisseton $^{\mathrm{a}}$ & 398 & 183 & 300 & 0.57 & 60.302 & 17 & 34.16 & 1.74 \\
\hline USA & George $^{a}$ & 286 & 179 & 233 & 0.34 & 30.599 & 17 & 10.40 & 2.26 \\
\hline USA & Amber ${ }^{\mathrm{a}}$ & 173 & 151 & 162 & 0.73 & 9.639 & 17 & 7.02 & 2.43 \\
\hline
\end{tabular}

a Data from Hanson and Stefan (1984).

b Data from this research.

c Data from Caleffi (2000). 


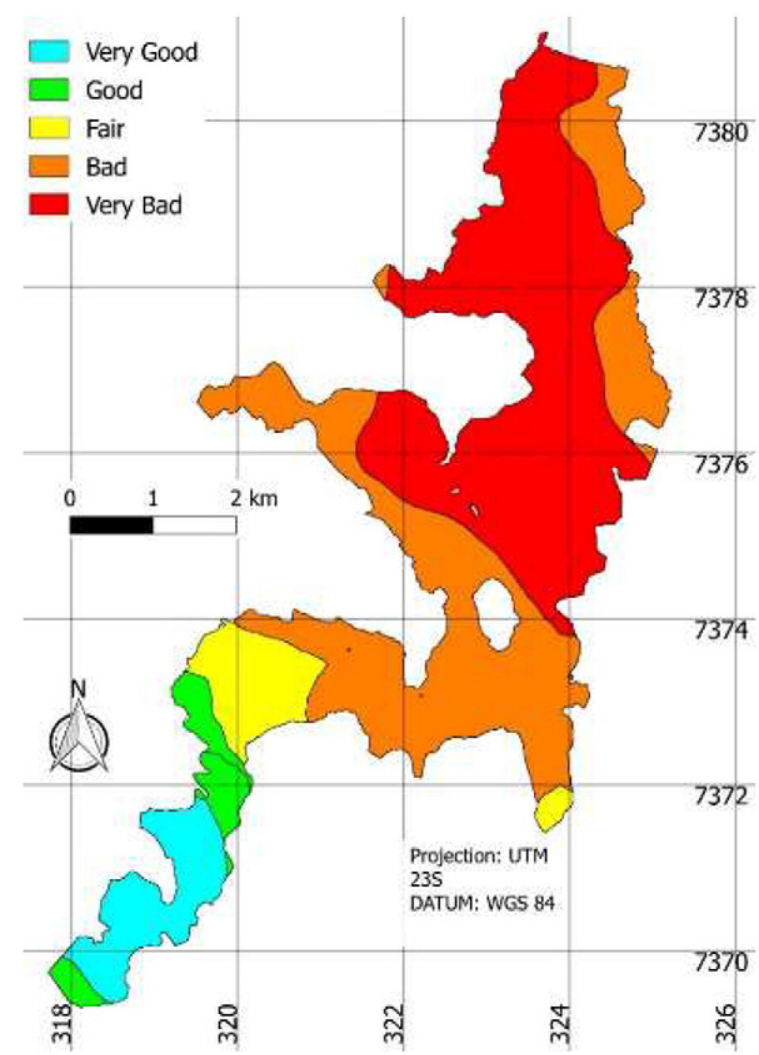

Fig. 6. Guarapiranga's sediment quality. Islands are in white.

treatment plants were unable to fully eliminate copper from the water distribution system. The copper deposited in the water supply reservoir could be resuspended back to the water column, hence possibly contaminating the water supply system and presenting a risk to the community. Mozeto and Zagatto (2006) also reported that dissolved copper could be found in the water column close to regions of substantial copper sulfate inputs. In the case of the Guarapiranga reservoir, the region with the highest sediment copper concentration was close to the extraction point used by SABESP to supply the RMSP (Fig. 5), increasing the potential risk to the population. Effler et al. (1980) found that in several systems that received large dosages of copper sulfate, the $\mathrm{Cu}^{2+}$ concentration remained elevated for up to several weeks, increasing the risk of copper contamination of water supplied from water bodies such as the Fairmont lakes or the Guarapiranga reservoir.

\subsubsection{Qualitative copper status}

The ELU sediment conditions for the Guarapiranga reservoir are shown in Fig. 6. Fig. 7 illustrates the proportions of the ELU quality

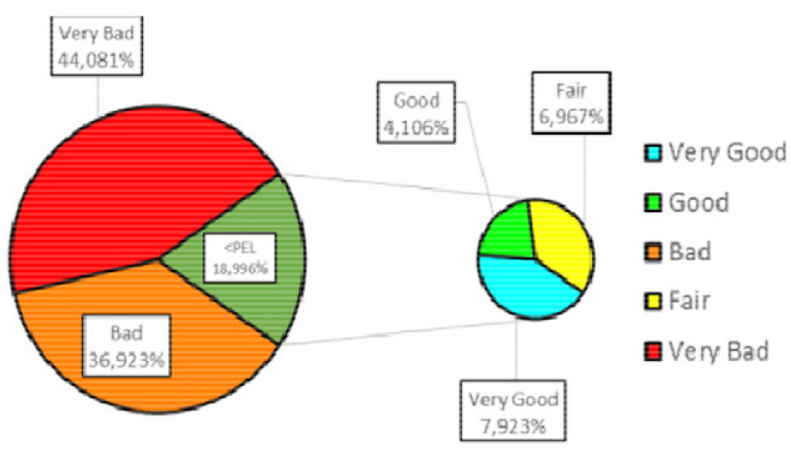

Fig. 7. Guarapiranga's ELU quality class coverage (percentage). classes, with $89 \%$ of the ELU area being above the ISQG, 52\% above the PEL, and 44\% 10-fold greater than the PEL, in agreement with previous reports (CETESB, 2013; Pompêo et al., 2013). The northern region of the reservoir, closer to the SABESP water collection system, showed the worst sediment quality (Fig. 6) and therefore presented the greatest toxicological risk, as discussed elsewhere (Mozeto and Zagatto, 2006; Hanson and Stefan, 1984).

These values clearly showed that the sediment of the Guarapiranga reservoir contained copper concentrations that greatly exceeded the values stipulated by the Contaminated Sediment Standing Team (2003), developed by MacDonald et al. (2000), with only 25\% of the surface area showing values below the ISQG. This was indicative of a potential threat to the ecosystem (EXTOXNET, 1994).

The same type of algal management policy is employed for other water bodies worldwide. In lakes of Minnesota, prolonged copper sulfate application resulted in various ecological alterations (Hanson and Stefan, 1984), some of which have been observed in the Guarapiranga reservoir. These include increased algal mortality and dissolved oxygen depletion (CETESB, 2013), enhanced phosphorus recycling and availability (Silva et al., 2013), and copper sulfate tolerance by algae (Beghelli et al., 2015; EXTOXNET, 1994; Mancuso, 1987; Raman and Cook, 1988). There has also been a shift in community species from chlorophytes to cyanobacteria (Effler et al., 1980; Mcknight, 1981; Silva, 2013a).

The Guarapiranga contains high levels of cyanobacteria cells in its water (CETESB, 2009), and there has been no indication of any improvement, despite the application of copper during several decades (CETESB, 2013). The application of copper in the Guarapiranga reservoir has therefore been ineffective. Furthermore, periodic applications can cause a series of side effects, including copper accumulation in the sediment (Arslan et al., 2010), leading to contamination of the water (ATKINSON et al., 2007) and changes in the composition and natural abundances of the different species of the ecosystem (Havens, 1994; Le Jeune et al., 2006; Santoro et al., 2009). There can be contamination of the water supply system (Hanson and Stefan, 1984; Mozeto and Zagatto, 2006) and potential bioaccumulation problems (Chiba et al., 2011; Yousafzai et al., 2012).

As previously described, the high copper concentration in the Guarapiranga sediment is due not only to the quantity of copper sulfate applied, but also to the long period of its application for palliative control of cyanobacteria and macrophytes by the company responsible for water quality.

Table 6 provides a comparison of the amounts of copper sulfate applied to different Brazilian subtropical reservoirs under SABESP management. Based on a price of $\mathrm{R} \$ 11.60$ for $1 \mathrm{~kg}$ of copper sulfate (SABESP, 2011a), the cost of the 1761 tons of copper sulfate pentahydrate applied to the Jundiaí, Guarapiranga, and Taiçupeba reservoirs, considering only the years $2005-2008$ is $\mathrm{R} \$ 20.43$ million (around US\$ 6.45 million, at current exchange rates) (Table 6).

Calculation was made of the sediment copper stock in the Guarapiranga reservoir. Using the kriging method, $[\mathrm{Cu}] 1.11 * 10^{--}$

${ }^{3} \mathrm{~kg}_{(\mathrm{Cu})} / \mathrm{kg}_{\text {(dry sediment) }}$; from the sediment sampling, $\mathrm{FS}=0.105_{(\mathrm{kg} \text { of }}$ fresh sediment), $\mathrm{Kv}=1.2 * 10^{-43}$ (m of fresh sediment), $h 0.04$ (meters of fresh sediment), and Wm $=81.20 * 10^{-3}(\mathrm{~kg}$ of water); from the bathymetric survey

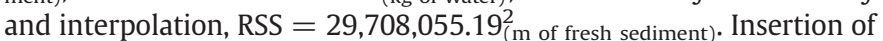
these values in the Stock equation resulted in a value of 1158.85 ton $_{\text {(copper), }}$, corresponding to eleven years of copper sulfate application. Extrapolation to a period of 43 years of constant copper application gave a value of 4530.05 tons of copper applied to the Guarapiranga reservoir.

Comparison of the 11 year stock value with the value stated in the SABESP copper sulfate application report revealed that our model overestimated the amount applied by around $46.94 \%$. This difference could be due to factors including the copper interpolation method, the bathymetric interpolation method, the reservoir margin delimitation, the reservoir landscape sedimentation rate, the diffuse copper input coming in from the Guarapiranga's watershed and the sediment water 
Table 6

Annual copper sulfate application in the Jundiaí, Guarapiranga and Braço Rio Grande (Billings) reservoirs for the years of 2006, 2007 e 2008.

\begin{tabular}{llllll}
\hline \multirow{2}{*}{ Reservoirs } & \multicolumn{5}{l}{ Tons of copper applied per year ${ }^{\mathrm{a}}$} \\
\cline { 2 - 5 } & 2005 & 2006 & 2007 & 2008 & 2011 \\
\hline Jundiaí & & $<20$ & 42 & & \\
Guarapiranga & 49 & 350 & 440 & 350 & 363 \\
$\begin{array}{l}\text { Rio Grande } \\
\text { Taiçupeba }\end{array}$ & & 150 & 360 & & 34 \\
\hline
\end{tabular}

a Values extracted from CETESB (2011).

component. Nevertheless, our stock estimate suggests that an enormous amount of copper was applied during the past 43 years.

An attempt was made to estimate the overall cost associated with the acquisition, storage, preservation, transport, and application of 4530.05 tons of copper (17,794.03 tons of copper sulfate pentahydrate) during the past 43 years (at present values in US\$). Based on the cost for a ton of this algicide (Table 7), and excluding the costs of handling and application at the reservoir, the estimated cost was US\$56,550,901.16. The total cost for the acquisition, shipping, storage, handling, and application of the algicide would be even higher. In an attempt to include other costs that were not accounted for, a safety coefficient of two times was applied to the equation. As a result, our estimated cost of copper sulfate application solely to the Guarapiranga reservoir is nearly US\$113 million.

The overall cost of phytoplankton control at the Guarapiranga reservoir should not be restricted solely to copper sulfate application, since $50 \%$ hydrogen peroxide has also been employed for the same purpose, especially after 1993 (Rocha, 1999). Fig. 8 illustrates the evolution of hydrogen peroxide application in the reservoir. In 2008 alone, application was made of 620 tons of hydrogen peroxide, in addition to 350 tons of copper sulfate (CETESB, 2009).

The overall cost of the algicides was estimated based on their usage rates reported by CETESB (2009, 2011, with an annual mean consumption of 641.48 tons of hydrogen peroxide for the Guarapiranga reservoir. According to Companhia Paulista de Obras e Serviços (CPOS, 2015), the bulk-shipping cost of hydrogen peroxide (including transportation and discharge) is around US\$0.33 per kilogram. Based on the 23 years of continuous hydrogen peroxide application at the reservoir, the total estimated cost is US\$3,880,503.15. Applying the same safety coefficient used above, our estimation suggests that almost US\$7.761 million have already been disbursed solely for hydrogen peroxide application to the Guarapiranga reservoir. Considering the costs of both hydrogen peroxide and copper sulfate, a total of nearly 120.9 million dollars has been spent on algae control at a single reservoir of São Paulo State.

In order to address our initial hypothesis, we also estimated the costs associated with a full water treatment program. Three main aspects were considered: a) sewage treatment plant (STP) installation, operational, and management costs in Brazil; b) the plant lot size and its price (US\$ $/ \mathrm{m}^{2}$ ); and c) costs of construction and commissioning of the plant. Assessment of these issues is very important for implementation of full sewage treatment, and the costs can vary greatly (Sampaio and Gonçalves, 1999; Lima, 2011; Pacheco, 2011). Factors to consider include the location of the proposed installation, the type of soil, the topography, the extent of the sewage system, the population density, and the type of equipment installed. In the present case, the estimated costs were for the construction and implementation of a sewage treatment plant suitable for 800,000 inhabitants, estimated to be the population of the reservoir basin (Whately and Cunha, 2005).

The STP of Barueri (a municipality in São Paulo State) serves around 4.4 million inhabitants, with a treated sewage flow of $8177 \mathrm{~L} / \mathrm{s}$ (SABESP, 2016). According to Sampaio and Gonçalves (1999), the running cost of the Barueri STP is around US\$261,233.97 per month, which is equivalent to a per capita sewage treatment cost of US $\$ 0.0594$ per month. Based on these values, the cost of an STP to serve the 800,000 inhabitants of the Guarapiranga basin would be US\$47,497.09 per month. Over a period of 43 years of sewage management and treatment, the total cost would be around US $\$ 24,508,496.09$.

For construction of the Guarapiranga STP, a worst-case scenario was assumed, with no existing sewage network. Therefore, a value of US $\$ 16,000,000.00$ was allowed for construction of the sewage collectors, interceptors, and connection systems required for all habitations in the Guarapiranga basin (Lima, 2011).

Pacheco (2011) estimated a total per capita cost of US\$54.79 for implementation of an STP. Therefore, the cost for such a system in the Guarapiranga basin would be US\$43,835,616.44.

The cost of land suitable for STP construction can vary widely. According to São Paulo State real estate agencies (using an internet search), prices in the Guarapiranga basin are no lower than US\$2.74 million for areas ranging from 50,000 to $100,000 \mathrm{~m}^{2}$.

Summation of the costs described above, including a period of 43 years of STP operation and the STP and sewage network construction costs, results in an estimated value of US\$98 million for full sewage treatment in the Guarapiranga basin. Taking into consideration possible difficulties and additional non-itemized expenses associated with $100 \%$ sewage treatment for almost 1 million inhabitants in the Guarapiranga basin, it is reasonable to assume a total cost of US\$87.08 million.

Based on the above estimates, it can be seen that the sum already spent for the control of algae in the Guarapiranga reservoir over 43 years is $28 \%$ higher than the cost of full sewage treatment in the drainage basin. Therefore, even ignoring possible losses of ecosystem services due to the use of algicides, the data suggest that the construction of a domestic sewage treatment facility would be both cheaper and more likely to solve the urgent problem of reservoir eutrophication. If the loss of ecosystem services is included (due to phytoplankton blooms and intensive algicide application), the sewage treatment plant option becomes even more financially viable. This argument is strengthened by the current need for further and continuous algicide applications, as a never-ending palliative measure. The use of algicide should be restricted to occasional events of sudden algal blooms or ineffectiveness of other water treatment strategies (ECC, 2000; Henriques et al., 2000; Pio et al., 2000, Pio and Henriques, 2000; Inag, 2006; Moss, 2008; Cardoso-Silva et al., 2013). Otherwise, the goal of zero untreated sewage discharge will never be achieved (Pompêo et al., 2015).

Another problem faced by public agencies and management planners is the increase of cyanobacteria density in reservoirs treated with copper sulfate, as a community response (adaptation) to the algicide (Mancuso, 1987; Raman and Cook, 1988; EXTOXNET, 1994). Examples of such cases can be seen for the Jundiaí, Guarapiranga, and Rio Grande (Billings) reservoirs, which all receive intense applications of copper sulfate but still present high densities of phytoplankton in their waters (CETESB, 2009; Moschini-Carlos et al., 2009; Beghelli et al., 2015). It is therefore clear that current Brazilian water quality management policy is not effective in the long term, with algicides losing their effectiveness in the control of algae and cyanobacteria, and it is expected that even

Table 7

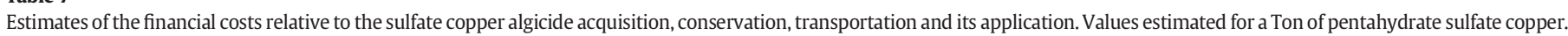

\begin{tabular}{|c|c|c|c|}
\hline Reference & Acquisition + shipping + discharge of 1 ton of copper sulfate & Real/dollar quotation & Quotation data: \\
\hline SABESP (Pregão 58749/10, 2011) ${ }^{a}$ & $\$ 3662.77$ & 3.167 & $18: 00$ of $05 / 13 / 16$ \\
\hline
\end{tabular}

a SABESP: Companhia de Saneamento Básico do Estado de São Paulo. 


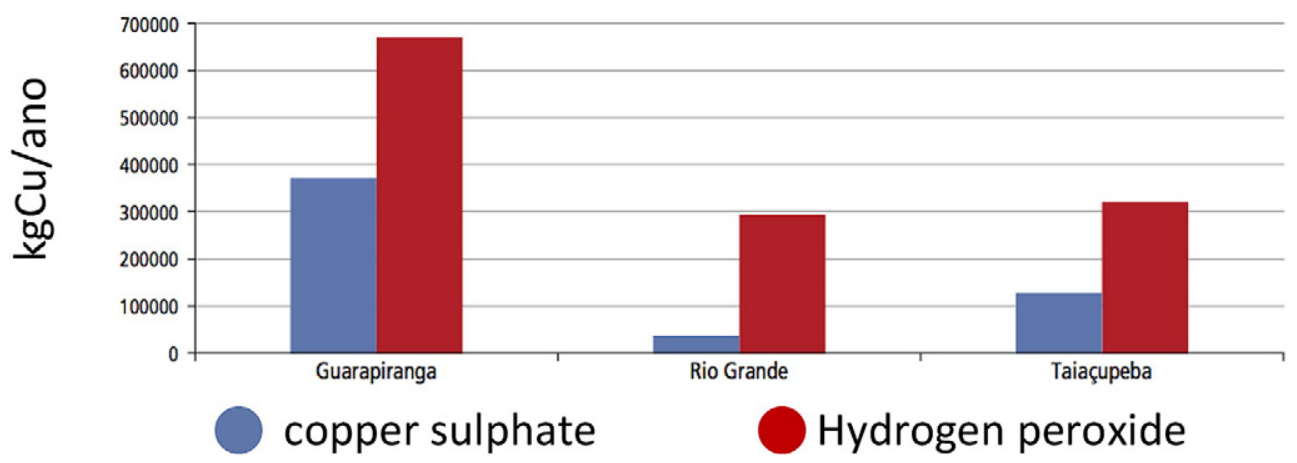

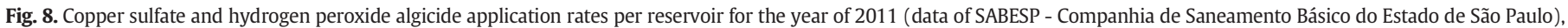
modified of CETESB (Companhia Ambiental do Estado de São Paulo, 2011).

greater quantities of algicide will be required over the next years, leading to further socioeconomic and environmental issues.

This work evaluates the current Guarapiranga reservoir management policy and its cost to the local economy. We also provide a comparison between the current management policy and an STP option. While this may not necessarily be the best solution, our results show how the Brazilian government could reevaluate its water management policy, without major socioeconomic impacts. Mention should be made here of two other water treatment and management techniques, in order to demonstrate the existence of other options. Hanson (1981) studied the cost-benefit of algal control in water treatment plants. It was found that it was more cost-effective to treat algal effects in the plant itself, rather than to treat the water resources with copper sulfate (Hanson and Stefan, 1984). In another study, Beaulieu et al. (2005) investigated the application of clay for the control of harmful algal blooms, with excellent results considering the cost of application and the effectiveness of the treatment. Such discoveries may well cause other countries to change their management methods, perhaps leading to a worldwide reservoir recovery. Nevertheless, it seems that Brazilian water management companies tend to focus on short-term water management techniques, without considering possible ecosystem service losses and without performing long-term cost-effect analyses in their management strategies.

\section{Conclusions}

The development of new quality evaluation models provides an important way to improve the understanding and management of increasingly anthropized ecosystems. In this work, evaluation is made of the applicability of geostatistics and ecotoxicological techniques as tools for water body management.

Ecotoxicological analysis showed that the copper concentration in the Guarapiranga reservoir sediment followed an irregular spatial distribution, with strong zonation, indicating different ecotoxicological quality conditions. There was evidence to suggest that the copper was not completely inert and attached to the sediment, but could potentially be solubilized and dispersed, hence enhancing ecotoxicological effects in the ecosystem and society (directly and indirectly).

Assessment was made of the total costs associated with the current policy for control of algae and cyanobacteria in a Brazilian tropical reservoir, and comparison was made with the cost of implementation of full domestic sewage treatment in the basin of the reservoir. This analysis revealed that: a) the total amount already spent on palliative methods for algal control in the Guarapiranga reservoir has already exceeded the amount required for effective long-term control by sewage treatment; b) the current management policy results in potential ecotoxicological risks to the ecosystem and to society, without genuinely improving the water quality of the reservoir; c) the current São Paulo State water management policy is mainly structured considering short-term financial costs, without adopting middle-term or long- term strategies, especially in relation to human health, ecosystem recovery, and restoration costs.

\section{Acknowledgements}

J.C. López-Doval received financial support from the Fundação de Amparo à Pesquisa do Estado de São Paulo (FAPESP 12/16420-6) and the Spanish Ministry of Economy and Competitiveness (IJCI-201523644).

A study scholarship was provided by Coordenação de Aperfeiçoamento de Pessoal de Nível Superior (CAPES).

We thank Empresa Metropolitana de Águas e Energia (EMAE) for provision of data for the Guarapiranga and Billings reservoirs.

We are grateful to Universidade de São Paulo (USP) for the provision of resources and qualified personnel.

\section{References}

Alcantara, E.H., 2008. Use of ordinary Kriging algorithm and wavelet analysis to understanding the turbidity behavior in an Amazon floodplain. J. Comput. Interdiscip. Sci. 1 (1), 57-70 DOI:106062.

Arslan, N., Koç, B., Ciçek, A., 2010. Metal contents in water, sediment, and OligochaetaChironomidae of Lake Uluabat, a Ramsar site of Turkey. Scientific World Journal 10: 1269-1281. https://doi.org/10.1100/tsw.2010.117.

Ashraf, M.A., Maah, M.J., Yusoff, I., 2012. Study of chemical forms of heavy metals collected from the sediments of tin mining catchment. Chem. Speciat. Bioavailab. 24:183-196. https://doi.org/10.3184/095422912X13406425859315.

Atkinson, C.A., Jolley, D.F., Simpson, S.L., 2007. Effect of overlying water pH, dissolved oxygen, salinity and sediment disturbances on metal release and sequestration from metal contaminated marine sediments. Chemosphere 69 (9), $1428-1437$.

Azevedo, L.B., van Zelm, R., Leuven, R.S.E.W., Hendriks, A.J., Huijbregts, M.A.J., 2015. Combined ecological risks of nitrogen and phosphorus in European freshwaters. Environ. Pollut. 200:85-92. https://doi.org/10.1016/j.envpol.2015.02.011.

Bai, J., Cui, B., Chen, B., Zhang, K., Deng, W., Gao, H., Xiao, R., 2011. Spatial distribution and ecological risk assessment of heavy metals in surface sediments from a typical plateau lake wetland, China. Ecol. Model. 222:301-306. https://doi.org/10.1016/j. ecolmodel.2009.12.002.

Barceloux, D.G., 1999. Copper. Clin. Toxicol. 37 (2), 217-230.

Bartram, J., Carmichael, W.W., Chorus, I., Jones, G., Skulberg, O.M., 1999. Toxic Cyanobacteria in Water: A Guide to Their Public Health Consequences, Monitoring and Management. St Edmundsbury Press, Bury St Edmunds, Suffolk, London and New York, Grã Bretanha.

Batista, L.F.A., 2011. Modelagem espaço-temporal da colonização de macrófitas submersas no Reservatório de Taquaruçu. Universidade Estadual Paulista - Campus de Presidente Prudente, Presidente Prudente, Brazil.

Bauzá, L., Aguilera, A., Echenique, R., Andrinolo, D., Giannuzzi, L., 2014. Application of hydrogen peroxide to the control of eutrophic lake systems in laboratory assays. Toxins 6:2657-2675. https://doi.org/10.3390/toxins6092657.

Beaulieu, S.E., Sengco, M.R., Anderson, D.M., 2005. Using clay to control harmful algal blooms: deposition and resuspension of clay/algal flocs. Harmful Algae 4:123-138. https://doi.org/10.1016/j.hal.2003.12.008.

Beghelli, F.G. De S., ROSA, A.H., Nishimura, P.Y., Meirinho, P. Do A., Leonardi, B.F., Guiduce, F.S., Lopez-Doval, J.C., Pompêo, M., Moschini-Carlos, V., 2015. Aplicações de sulfato de cobre no reservatório guarapiranga, sp: distribuição no meio e efeitos sobre a comunidade planctônica. Ecologia de Reservatórios E Interfaces, pp. 294-308 (São Paulo, Brasil).

Beyruth, Z., 1996. Comunidade fitoplanctônica da represa de Guarapiranga: 1991-92: aspectos ecológicos, sanitários e subsídios para reabilitação ambiental. 1996. (191p. 
Doctoral Tesis). Faculdade de Saúde Pública, Universidade de São Paulo, São Paulo, Brazil.

Bonai, N.C., Souza-Franco, G.M., Fogolari, O., Mocelin, D.J.C., Dal Magro, J., 2009. Distribution of metals in the sediment of the Itá reservoir, Brazil. Acta Limnol. Bras. 21 (2), 245-250.

Bourke, A.T.C., Hawes, R.B., Neilson, A., Stallman, N.D., 1983. An outbreak of hepato-enteritis (the Palm Island mystery disease) possibly caused by algal intoxication. Toxicon $3,45-48$.

Brasil, 2011. Ministério da Saúde. Portaria MS no 2914/2011. Dispõe sobre os procedimentos de controle e de vigilância da qualidade da água para consumo humano e seu padrão de potabilidade. Ministério da Saúde.

Burgos-León, A.M., Valdés, D., Vega, M.E., Defeo, O., 2012. Spatial structuring of submerged aquatic vegetation in an estuarine habitat of the Gulf of Mexico. J. Mar. Biol. Assoc. U. K. 93:855-866. https://doi.org/10.1017/S0025315412000677.

Byth, S., 1980. Palm Island mystery disease. Med. J. Aust. 2, 40-42.

Cairns, J., Niederlehner, B.R., 1996. Developing a field of landscape ecotoxicology. Ecol. Appl. 6:790-796. https://doi.org/10.2307/2269484.

Caleffi, S., Oliveira Neto, A.L., 2000. Impacto do uso de sulfato de cobre sobre o zooplâncton na Represa Guarapiranga. In: Espíndola, E.L.G. Paschoal, C.M.R.B., Rocha, O., Bohrer, M.B.C. (Eds.), Ecotoxicologia: perspectivas para o Século XXI. São Carlos, Brasil, RiMa.

Camargo, E.C.G. Monteiro, A.M.V., Felgueiras, C.A., Fuks, S.D., 1999. Integração de Geoestatística e Sistemas de Informação Geográfica: Uma Necessidade. p. 11.

Camargo, E.C.G., Felgueiras, C.A., Monteiro, A.M.V., 2001. A Importância da Modelagem da Anisotropia na Distribuição Espacial de Variáveis Ambientais Utilizando Procedimentos Geoestatísticos. Anais X SBSR, Foz Do Iguaçu, 21-26 Abril 2001. 20. INPE, Brazil, pp. 395-402.

Campagnoli, F., 2002. A aplicação do assoreamento na definição de Geoindicadores ambientais em áreas urbanas - Exemplo na Bacia do Alto Tietê. SP. Universidade de São Paulo (BRASIL). Politécnica da USP (POLI) (Tese de Doutoramento).

Canadian Council of Ministers of the Environment, 1999. Canadian sediment quality guidelines for the protection of aquatic life: protocol of the derivation of Canadian sediment quality guidelines for the protection of aquatic life. EPC-98E. CCME, p. 35 .

Cardoso-Silva, S., Ferreira, T., Pompêo, M., 2013. Diretiva quadro da água: uma revisão crítica e a possibilidade de aplicação ao Brasil. Ambiente Soc. 16 (1), 39-58.

Carvalho, N.O., 1994. Hidrossedimentologia prática. CPRM, Eletrobrás, Rio de Janeiro, RJ.

CETESB, 2002. Companhia de Tecnologia de Saneamento Ambiental. Relatório de qualidade das águas interiores do estado de São Paulo 2001. CETESB, Secretaria de Estado do Meio Ambiente, São Paulo, p. 232

Chen, J., Wei, F., Zheng, C., Wu, Y., Adriano, D.C., 2013. Background concentrations of elements in soils of China. J. Chem. Inf. Model. 53:1689-1699. https://doi.org/10.1017/ CBO9781107415324.004.

Chiba, W., Passerini, M., Tundisi, J., 2011. Metal contamination in benthic macroinvertebrates in a sub-basin in the southeast of Brazil. Braz. J. Biol. 71 (2), 391-399.

Codd, G.A., Azevedo, S.M.F.O., Bagchi, S.N., Burch, M.D., Carmichael, W.W., Harding, W.R. Kaya, K. Utkilen, H.C. 2005. CYANONET: a global network for cyanobacterial bloom and toxin risk management. Initial Situation Assessment and Recommendations, INTERNATIONAL HYDROLOGICAL PROGRAMME. UNESCO, Paris, France.

Companhia Ambiental do Estado de São Paulo (CETESB), 2011. Qualidade das Águas superficiais no Estado de São Paulo. São Paulo, Brazil. Retrieved from. http:// aguasinteriores.cetesb.sp.gov.br/publicacoes-e-relatorios/.

CETESB, 2012. Companhia Ambiental do Estado de São Paulo. Relatório: qualidade das águas superficiais no Estado de São Pauo - 2011. CETESB, São Paulo.

Companhia Ambiental do Estado de São Paulo (CETESB), 2013. Qualidade das águas superficiais no Estado de São Paulo. São Paulo, Brasil. Retrieved from. http://www. cetesb.sp.gov.br/userfiles/file/agua/aguas-superficiais/relatorio-aguas-superficiais2013-parte1.pdf.

Companhia Ambiental do Estado de São Paulo (CETESB), 2015. Qualidade das águas superficiais no Estado de São Paulo. São Paulo, Brasil. Retrieved from:. http:// aguasinteriores.cetesb.sp.gov.br/wp-content/uploads/sites/32/2013/11/Cetesb_ QualidadeAguasSuperficiais2015_Partel_25-07.pdf.

Companhia Ambiental do Estado de São Paulo (CETESB), Relatório de qualidade das águas interiores do Estado de São Paulo, referente aos anos de 2003, 2006, 2007. 2008 e 2009. São Paulo: Secretaria do Meio Ambiente, (Série Relatórios Técnicos, publicados respectivamente nos anos 2004, 2007, 2008, 2009 e 2010). Retrieved from:. http://www.cetesb.sp.gov.br/.

Companhia de Saneamento Básico do Estado de São Paulo (SABESP), 2011. Ata da Sessão Pública 58749/10. Objeto: Fornecimento de Sulfato de Cobre para Tratamento de Água - Compra Estratégica.

Companhia de Saneamento Básico do Estado de São Paulo (SABESP), 2011. Problema com algas na represa do Guarapiranga deve ser resolvido em dez dias. Retrieved from. http://www.blogsabesp.com.br/1931/problema-com-algas-na-represa-doguarapiranga-deve-ser-resolvidoem-dez-dias (Assess in: 09/12/2011).

Companhia de Saneamento Básico do Estado de São Paulo (SABESP), 2014. In: Hildebrand, A., Tonello, J.P.N., Silva, P.C. da (Eds.), Relatório de sustentabilidade (2014. São Paulo - SP, Brazil).

Companhia de Saneamento Básico do Estado de São Paulo (SABESP), 2016. ETE Barueri. Retrieved from:. http://site.sabesp.com.br/site/interna/Default.aspx?secaold=56 (Assess in: Aug of 2016).

Companhia Paulista de Obras e Serviços (CPOS), Companhia de Desenvolvimento Agrícola de São Paulo (CODASP), Companhia de Saneamento Básico do Estado de São Paulo (SABESP), Empresa Metropolitana de Transportes Urbanos de São Paulo (EMTU), 2015. Retificação do Edital do pregão. Julgamento e adjudicação Retrieved from. http://sabespinfo18.sabesp.com.br/Licita/pg_Int.nsf/Atas/EA45D1E988001C2483257 830005F36CC/\$File/AtaPregao58749-10.html> (Assessed in: Jun. 07 of 2016).
Contaminated Sediment Standing Team, 2003. Consensus-based sediment quality guidelines recommendations for use \& application - interim guidance. Interim Guidance, p. 35 (December).

Correll, D.L., 1998. The role of phosphorus in the eutrophication of receiving waters: a review. J. Environ. Qual. 27:261. https://doi.org/10.2134/jeq1998.00472425002700020004x.

Cressie, N.A., 1993. Statistics for Spatial Data. Rev. ed. John Wiley \& Sons, New York (928 pp.) Danton, W., Bilhalva, D.B., 2013. Batimetria de Pequenos Reservatórios através de Metodologia Convencional e Alternativa. Universidade Federal de Santa Maria, Brasil. Dissertação de mestrado apresentada ao Curso de Mestrado do Programa de Pós Graduação em Geomática, Área de Concentração Tecnologia da Geoinformação, da Universidade Federal de Santa Maria. UFSM, RS.

ECC (European Community Commission), 2000. Commission Directive 2000/60/EC of the European Parliament and the council establishing the framework for community action.

Dekker, A.G., Brando, V.E., Anstee, J.M., 2005. Retrospective seagrass change detection in a shallow coastal tidal Australian lake. Remote Sens. Environ. 97:415-433. https://doi. org/10.1016/j.rse.2005.02.017.

Effler, S.W., Litten, S., Field, S.D., Tong-Ngork, T., Hale, F., Meyer, M., Quirk, M., 1980. Whole lake responses to low level copper sulfate treatment. Water Res. 14:1489-1499. https://doi.org/10.1016/0043-1354(80)90015-9.

Eiger, S., Aranha, C.H., de Gomes, M.C.A., Perez, L.S.N., Neto, A.S.B., 2012. Modelagem Matemática de Cargas Difusas na Bacia do Guarapiranga, São Paulo. XIII Simpósio Brasileiro de Recursos Hídricos:pp. 1-24 https://doi.org/10.1007/s13398-014-017372

EMAE, Empresa Metropolitana de Águas e Energia S.A., 2007. Assess in:. http://www. emae.sp.gov.br/.

de Esteves, F., 1998. A. Fundamentos de Limnologia. 2.ed. Interciência, Rio de Janeiro.

Extension Toxicology Network (EXTOXNET), 1994. Pesticide Information Project of Cooperative Extension Offices of Cornell University. Michigan State University (Retrieved from: Networkhttp://pmep.cce.cornell.edu/profiles/extoxnet/carbaryl-dicrotophos/ copper-sulfate-ext.html)

Feist, B.E., Buhle, E.R., Arnold, P., Davis, J.W., Scholz, N.L., 2011. Landscape ecotoxicology of coho salmon spawner mortality in urban streams. PLoS One 6. https://doi.org/10. 1371/journal.pone.0023424.

Focks, A., 2014. The challenge: landscape ecotoxicology and spatially explicit risk assessment. Environ. Toxicol. Chem. 33 (6):1193 Retrieved from: http://dx.doi.org/10 1002/etc.2568.

Ford, D.E., 1990. Reservoir Transport Processes. In: Thornton, K.W., Kimmel, B.L., Payne, F.E. (Eds.), Reservoir Limnology. Ecological Perspectives. Wiley-Interscience, New York, pp. 15-41.

Fornes, A., Basterretxea, G., Orfila, A., Jordi, A., Alvarez, A., Tintore, J., 2006. Mapping Posidoniaoceanica from IKONOS. ISPRS J. Photogramm. Remote Sens. 60:315-322. https://doi.org/10.1016/j.isprsjprs.2006.04.002.

Förstner, U., Wittmann, G.TW., 1981. Metal Pollution in the Aquatic Environment. 2 . Springer-Verlag, Berlin Heidelberg. https://doi.org/10.1007/978-3-642-69385-4 (Softcover ISBN: 978-3-540-12856-4. ISSN: 0172-6234. 48 pp.).

Gharibreza, M., Raj, J.K., Yusoff, I., Ashraf, M.A., Othman, Z., Tahir, W.Z.W.M., 2013. Effects of agricultural projects on nutrient levels in Lake Bera (Tasek Bera), Peninsular Malaysia. Agric. Ecosyst. Environ. 165:19-27 Retrieved from: http://dx.doi.org/10 1016/j.agee.2012.12.004

Golterman, H.L., Sly, P.G., Thomas, R.L., 1983. Study of the Relationship Between Water Quality and Sediment Transport. 226. Scientific and Cultural Organization.

Guimarães, G.M., 2011. Avaliação da concentração de metais e elementos traço em amostras de sedimento do Reservatório Guarapiranga, São Paulo-SP, Brasil. 2011. 171 f. Dissertação (Mestrado). Universidade de São Paulo, São Paulo, Brasil.

Graham, J.L., Loftin, K.A., Ziegler, A.C., Meyer, M.T., 2008. Cyanobacteria in lakes and reservoirs- Toxin and taste-and-odor sampling guidelines (ver. 1.0): U.S. Geological Survey Techniques of Water Resources Investigations. book 9, chap. A7, section 7.5, September, accessed in: Nov 29 of 2016. Retrieved from. http://pubs.water.usgs. gov/twri9A/

Hanson, M.J., 1981. The Use of Copper Sulfate for Algal Control; Copper Treatments in the Fairmont Lakes 1921-1979. Fairmont Lakes Commission Report No. 5, Fairmont, Minnesota.

Hanson, M.J., Stefan, H.G., 1984. Side effects of 58 years of copper sulfate treatment of the Fairmont Lakes, Minnesota. J. Am. Water Resour. Assoc. 20 (6):889-900. http://dx. doi.org/10.1111/j.1752-1688.1984.tb04797.x.

Hassler, T.J., 1969. Biology of the Northern pike in Oake reservoir, 1959 thorugh 1965 Tech.Pap. U.S. Fish Wildl. Serv., (29) 13 pp.

Havens, K.E. 1994. An experimental comparison of the effects of two chemical stressors on a freshwater zooplankton assemblage. Environ. Pollut. 84, 245-251.

Henriques, A.G., West, C.A., Pio, S., 2000. Directiva quadro da água um instrumento integrador da política da água da União Europeia. Congresso Da Água, 5., 2000, Lisboa. Anais.... Associação Portuguesa dos Recursos Hídricos, Lisboa 19 pp.

Holtzman, N.A., Elliott, D.A., Heller, R.H., 1966. Copper intoxication. Report of a case with observations on ceruloplasmin. N. Engl. J. Med. 275, 347-352.

Horn, B.K.P., 1981. Hill shading and the reflectance map. Proc. IEEE 69:14-47. https://doi. org/10.1109/PROC.1981.11918.

Huh, J.-H., Ahn, J.-W., 2017. A perspective of chemical treatment for cyanobacteria control toward sustainable freshwater development. Environ. Eng. Reserv. (22), 1-11.

INAG, 2006. Instituto Da Água (Portugal). Implementação da Directiva Quadro da Água: 2000-2005. INAG, Lisboa 16 pp.

Jiang, C., Xhu, L., Hu, X., Cheng, J., Xie, M., 2010. Reasons and control of eutrophication in new reservoirs. In: Ansari, Abid A Sarvajeet, Singh Gill, Lanza, Guy R, R, W. (Eds.) Eutrophication: Causes, Consequences and Control. Springer:p. 394 https://doi.org/ 10.1007/978-90-481-9625-8 (chap. 16).

John, D.A., Leventhal, J.S., 1995. Bioavailability of metals, 90 U.S. Geophys. Surv. https:// doi.org/10.13140/RG.2.2.28846.51525 
Kansole, M., Lin, T.-F., 2017. Impacts of hydrogen peroxide and copper sulfate on the control of Microcystis aeruginosa and MC-LR and the inhibition of MC-LR degrading bacterium bacillus sp. Water 9 (4):255. http://dx.doi.org/10.3390/w9040255.

Kleerekoper, H., 1939. Estudo Limnológico da Represa de Santo Amaro em São Paulo (São Paulo - SP, Brazil)

Korosi, J.B., Smol, J.P., 2012. Examining the effects of climate change, acidic deposition, and copper sulphate poisoning on long-term changes in cladoceran assemblages. Aquat. Sci. 74:781-792. https://doi.org/10.1007/s00027-012-0261-8.

Krieger, R.I., 2001. Handbook of Pesticide Toxicology Agents. 2nd ed. vol. 2. Academic Press, Inc., San Diego, CA, pp. 1361-1362.

Lage, F., 2013. Aplicação da Tríade de Qualidade do Sedimento em análise espacial no reservatório Guarapiranga (SP, Brasil). Doctoral Thesis in Ecology by the Instituto de Biociências, Universidade de São Paulo. São Paulo, Brazil. 2006. Universidade de São Paulo, São Paulo, Brasil.

Le Jeune, A.-H., et al., 2006. Effect of copper sulphate treatment on natural phytoplanktonic communities. Aquat. Toxicol. 80 (3), 267-280.

Lima, E.C., 2011. Infraestrutura Urbana. Saneamento: Coletores Tronco Tietê, Third edition Retrieved from:. http://infraestruturaurbana.pini.com.br/solucoes-tecnicas/3/ artigo215121-2.aspx (Assessed in: 08 Aug 2016).

Lürling, M., Meng, D., Faassen, E.J., 2014. Effects of hydrogen peroxide and ultrasound on biomass reduction and toxin release in the cyanobacterium, Microcystis aeruginosa. Toxins (Basel). vol. 9 (6), 3260-3280.

Macdonald, D.D., Ingersoll, C.G., Berge, T.A., Berger, T.A., 2000. Development and evaluation of consensus-based sediment quality guidelines for freshwater ecosystems. Arch. Environ. Contam. Toxicol. 39:20-31. https://doi.org/10.1007/sOM440010075.

Machado, P.L.O. de A., Bernardi, A.C. de C., Silva, C.A., 2004. Agricultura de Precisão para o Manejo da Fertilidade do Solo em Sistema Plantio Direto. 1st ed. Embrapa Solos, Rio de Janeiro - RJ, Brasil.

Maier, M.H., 1985. Limnologia de reservatórios do sudoeste do estado de São Paulo, Brasil. II Circulação e estratificação da água. B. Inst. Pesca 12 (1), 11-43.

Maier, M.H., Takino, M., 1985. Limnologia de reservatórios do sudoeste do estado de São Paulo, Brasil. III - Qualidade da água. B. Inst. Pesca 12 (1), 45-73.

Mancuso, P.C.S., 1987. Controle do Desenvolvimento de Algas em Águas de Abastecimento Público. Rev. DAE. 47 pp. 151-156

Mariani, C.F., Pompêo, M.L., 2008. Potentially bioavailable metals in sediment froma tropical polymictic environment-Rio Grande reservoir, Brazil. J. Soils Sediments 8 (5), 284-288.

Margalef, R., Planas, D., Armengol, J., Vidal, A., Prat, N., Guiset, A., Toja, J., Estrada, M., 1976 Limnología de los embalses españoles. Ministerio de Obra Pública-Direción Genera de Obras Hidráulicas, Madrid (462 pp.).

Matthijs, H.C.P., Visser, P.M., Reeze, B., Meeuse, J., Slot, P.C., Wijn, G., Talens, R., Huisman, J 2012. Selective suppression of harmful cyanobacteria in an entire lake with hydrogen peroxide. Water Res. 46:1460-1472. https://doi.org/10.1016/j.watres.2011.11.016.

McKnight, D., 1981. Chemical and biological processes controlling the response of a fresh water ecosystem to copper stress: a field study of the CuSO4 treatment of Mill Pond Reservoir, Burlington, Massachusetts. Limnol. Oceanogr. 26, 518-531.

Melchor, A., Silveira, A., Lopez, G.M., Araujo, R., 1975. Preservação de mananciais para abastecimento: Guarapiranga- um modelo para preservação. DAE 35, 14-25.

Melo, G.M.P. de, Melo, V.P. de, Melo, W.J. de, 2006. Metais Pesados no Ambiente Decorrente da Aplicação de Lodo de Esgoto em Solo Agrícola. Ministério do Meio Ambiente, Brasil, Brasília, DF 2006. Retrieved from:. http://www.mma.gov.br/port/ conama/processos/CB5F6214/LODOMETAL.pdf (Assess in: Mar. 09 of 2015)

Mitas, L., Mitasova, H., 1999. Spatial interpolation. Geogr. Inf. Syst. Princ. Tech. Manag. Appl. 481-492.

Moss, B., 2008. The water framework directive: total environment or political compromise? Sci. Total Environ. 400 (1-3), 32-41.

Moschini-Carlos, V., Bortolli, S., Pinto, E., Nishimura, P.Y., Freitas, L.G., Pompêo, M.L.M. Dorr, F., 2009. Cyanobacteria and cyanotoxin in the billings reservoir (São Paulo, SP, Brazil). Limnetica 28 (2), 273-282.

Mozeto, A.A., Zagatto, P.A., 2006. Introdução de agentes químicos no ambiente. In: Zagatto, P.A., Bertoletti, E. (Eds.), Ecotoxicologia aquática: métodos e aplicações. Rima, São Carlos, pp. 15-38.

Mozeto, A.A., Silvério, P.F., Soares, A., 2001. Estimates of benthic fluxes of nutrients across the sediment-water interface (Guarapiranga reservoir, São Paulo, Brazil). Sci. Total Environ. 266, 135-142.

NASCIMENTO, R.L.D., 2003. Proposição de valores de referência para concentração de metais e metaloides em sedimentos límnicos e fluviais da Bacia Hidrográfica do Rio Tietê, SP. 2003. 142 p. Tesis (Doctoral) - Instituto de Química, Universidade Federal de São Carlos, São Carlos, Breazil.

Nishimura, P.Y., 2012. A comunidade fitoplanctônica nas represas Billings e Guarapiranga (Região Metropolitana de São Paulo). Universidade de São Paulo, São Paulo, Brasil.

Nordstrom, D., Alpers, C., Coston, J., Taylor, H., Blaine Mccleskey, R., Ball, J.W., ... Davis, J.A 1999. Geochemistry, Toxicity, and Sorption Properties of Contaminated Sediments and Pore Waters From Two Reservoirs Receiving Acid Mine Drainage. Published Research. Paper 487, (Cd), 10. Retrieved From. http://digitalcommons.unl.edu/ usgsstaffpub/487/.

Oliveira, et al., 2013. (Coord.). Análise Geoambiental da Reserva da Biosfera do Cinturão Verde da Cidade de São Paulo e da Bacia do Guarapiranga. Relatório Geoambiental 327 pp. + Anexos.

Pacheco, R.P., 2011. Custos Para Implantação De Sistemas De Esgotamento Sanitário. 112 Retrieved from:. http://acervodigital.ufpr.br/bitstream/handle/1884/29604/R\%20-\% 20D\%20-\%20RODRIGO\%20PINHEIRO\%20PACHECO.pdf?sequence=1 (Assess in: Aug 8 of 2016).

Padial, P.R., 2008. Qualidade, heterogeneidade espacial e biodisponibilidade de metais no sedimento de um reservatório tropical urbano eutrofizado (Reservatório Guarapiranga, SP). São Paulo, Brasil.
Padovesi-Fonseca, C., Philomeno, M.G., 2004. Effects of algicide (copper sulfate) application on short-term fluctuations of phytoplankton in Lake Paranoá, central Brazil. Braz. J. Biol. 64, 819-826.

Pedrozo, M.F.M., 2003. Cobre. In: Chasin, A.A.M., Azevedo, F.A. (Eds.), Metais: Gerenciamento da Toxicidade. Intertox, São Paulo (554 pp.).

Pelley, J., 2016. Taming toxic algal blooms. ACS Cent. Sci. 91:270-273. https://doi.org/10. $1111 / 1462$.

Pio, S., Henriques, A.G., 2000. O estado ecológico como critério para a gestão sustentável das águas de superfície. Congresso Da Água, 5., 2000, Lisboa. Anais... Associação Portuguesa dos Recursos Hídricos, Lisboa.

Pio, S., West, C.A., Henriques, 2000. Protecção das águas de superfície contra a poluição por substâncias perigosas no âmbito da Directiva-Quadro da Água. In: CONGRESSO DA ÁGUA, 5., 2000, Lisboa. Anais... Lisboa: Associação Portuguesa dos Recursos Hídricos, 2000. Disponível em Acess em: 01 maio 2010.

Pompêo, M.L.M., Padial, P.R., Mariani, C.F., Cardoso-Silva, S., Moschini-Carlos, V., Silva, D.C.V.R. da, ... Brandimarte, A.L., 2013. Biodisponibilidade de metais no sedimento de um reservatório tropical urbano (reservatório Guarapiranga - São Paulo (SP), Brasil): há toxicidade potencial e heterogeneidade espacial? Geochim. Bras. 27 (2): 104-119. https://doi.org/10.5327/Z0102-9800201300020003.

Pompêo, M., Moschini-Carlos, V., Nishimura, P.Y., Silva, S.C. da, López-Doval, J.C., 2015. Ecologia de Reservatórios e interfaces. 1st ed. vol. 1 São Paulo - SP, Brasil. Retrieved from. http://ecologia.ib.usp.br/reservatorios/>.

Qin, B.Q., Gao, G., Zhu, G.W., Zhang, Y.L., Song, Y.Z., Tang, X.M., et al., 2013. Lake eutrophication and its ecosystem response. Chin. Sci. Bull. 58 (9):961-970. https://doi.org/10. 1007/s11434-012-5560-x (2013).

Queiroz, W. de, 2014. Análise geoambiental da bacia contribuinte do reservatório guarapiranga (sp) para avaliação da produção de sedimentos. Master's dissertation by the Universidade Guarulhos. Departamento of Geoenvironmental analysis, Guarulhos - SP, Brazil.

Raloff, J., 2002. Taming toxic tides: can we slay poisonous algal blooms with clay? Sci. News 162, 344-345.

Raman, R.K., Cook, B.C., 1988. Guidelines for Applying Copper Sulfate as an Algicide: Lake Loami Field Study. ILENR/RD-WR-88/19. Springfield, Ill.

Rast, W., Holland, M., Ryding, S., 1989. Eutrophication management framework for the policy-maker. MA B Digest 1. Unesco, Paris.

Resck, R.P., Neto, J.F.B., Coelho, R.M.P. 2007. Nova batimetria e avaliação de parâmetros morfométricos da Lagoa da Pampulha (Belo Horizonte, Brasil). Geografias 3, 17-23.

Rocha, S.M., 1999. Macroinvertebrados bentônicos como indicadores de poluição na represa do guarapiranga - SP. Universidade de São Paulo, Brazil (Retrieved from: file://C:/Users/PhilipeLeal/Downloads/mestradosolange1999.pdf $>$ ).

Sá, N. de, 2014. Narcélio de Sá - Geotecnologias. CreativeCommons - Atribuição 4.0 Internacional Licence. Powered by WordPress Retrieved from:. http://narceliodesa. com/calculando-declividade-qgis/.

Sampaio, A.O., Gonçalves, M.C., 1999. Custos operacionais de estações de tratamento de esgoto por lodos ativados: estudo de caso ETE - Barueri, $20^{\circ}$ Congresso Brasileiro de Engenharia Sanitária e Ambiental, $3^{\circ}$ Feira Internacional de Tecnologias de Saneamento Ambiental. :pp. 676-685 Retrieved from:. http:// www.bvsde.paho.org/bvsaidis/brasil20/i-130.pdf (Rio de Janeiro, RJ, Assessed in Aug 8 of 2016)

Santoro, A., et al., 2009. Bioaccumulation of heavy metals by aquatic macroinvertebrates along the Basento River in the South of Italy. Water Air Soil Pollut. 201 (1-4), 19-31.

Saravu, K., Jose, J., Bhat, M.N., Jimmy, B., Shastry, B., 2007. Acute ingestion of copper sulfate: a review on its clinical manifestations and management. Indian J Crit Care Med 11, 74-80.

Sárközy, F., 1998. Gis functions - interpolation. PeriodicaPolytechnica Civil Engineering. Budapest. Technical University Budapest. Department of Surveying Hungary April 3th. Retrieved from:. http://www.agt.bme.hu/public_e/funcint/funcint.html (Assessed in: Nov 11 of 2016).

Sawyer, P.J., Gentile, J.H., Sasner Jr., J.J., 1968. Demonstration of a toxin from Aphanizomenon flosaquae (L.) Ralfs. Can. J. Microbiol. 14, 1199-1204.

Schropp, S.J., Lewis, F.G., Windom, H.L., Ryan, J.D., Calder, F.D., Burney, L.C., 1990. Interpretation of metal concentrations in estuarine sediments of Florida using aluminum as a reference element. Estuaries 13 (3), 227-235.

Schunk, F., 2013. Bacia hidrográfica do reservatório Guarapiranga. Assess in:. http://www. conservation.org.br/publicacoes/files/avesmigratorias/sudeste/AVESSE_ guarapiranga.pdf.

Shafie, N.A., Aris, A.Z., Zakaria, M.P., Haris, H., Lim, W.Y., Isa, N.M., 2013. Application of geoaccumulation index and enrichment factors on the assessment of heavy metal pollution in the sediments. J. Environ. Sci. Health A 48 (2), 182-190.

Silva, J. de P., 2005. Expansão Urbana e Evolução Geomorfológica em Remansos de Reservatórios: Análise Comparativa de duas Bacias Hidrográficas em Guarapiranga, São Paulo. Letras e Ciências Humanas. Universidade de São Paulo. Faculdade de Filosofia (Dissertação de Mestrado).

Silva, S.C. da, 2008. Heterogeneidade espacial e a qualidade das águas superficiais do reservatório Guarapiranga (São Paulo- SP- Brasil). Universidade de Sao Paulo, Brazil (Dissertação de Mestrado).

Silva, L.F. da, 2013. Reconstrução Paleolimnológica da Eutrofização na Represa Guarapiranga com base em Multitraçadores Biogeoquímicos. Universidade Estadual Paulista (UNESP), Brazil Retrieved from. http://citeseerx.ist.psu.edu/viewdoc/ download?doi=10.1.1.630.5576\&rep $=$ rep $1 \&$ type $=$ pdf.

Silva, S.C. da 2013. Metais-traço em Sedimentos do Reservatório Paiva Castro (Mairiporã-São Paulo): histórico por meio da geocronologia do Pb210, biodisponibilidade e uma proposta para a gestão dos recursos hídricos. Universidade de São Paulo (Tese de Doutorado em Ciências, na Área de Ecologia (Tese de Doutorado)). 
Silva, D.B., Monteiro, L.R., Generoso, M.F., Bicudo, C., Bicudo, D., Cotrim, M.E.B., Pires, M.A.F., 2013. Estudo Sobre Ferro E Fósforo Nas Águas E Sedimentos Da Represa Guarapiranga São Paulo-Brasil. XX Simpósio Brasileiro de Recursos Hidricos. Associação Brasileira de Recursos Hídricos, Bento Gonçalves, Brazil, pp. 1-8.

Sinkovic, A., Strdin, A., Svensek, F., 2008. Severe acute copper sulphate poisoning: a case report. Arh. Hig. Rada Toksikol. 59, 31-35.

Singh, M.M., Singh, G.S., 1968. Biochemical changes in blood in cases of acute copper sulfate poisoning. J. Indian Med. Assoc. 50, 549-554

Smal, et al., 2015. Spatial distribution and risk assessment of heavy metals in bottom sediments of two small dam reservoirs (south-east Poland). Arch. Environ. Prot. 41 (4), 67-80.

Smith, M.W., 1939. Copper sulphate and retonone as fish poisons. Trans. Am. Fish. Soc. 69, 141.

Smith, K.S., 2007. Strategies to predict metal mobility in surficial mining environments. Eng. Geol. XVII (3):25-45, https://doi.org/10.1130/2007.4017(03).

Souza, V.A., Wasserman, J.C., 2015. Distribution of heavy metals in sediments of a tropical reservoir in Brazil: sources and fate. J. S. Am. Earth Sci. 63, 208-216.

Sperling, V., 1999. Morfologia de lagos e Represas, Morfologia de lagos e Represas. Belo Horizonte: DESA/UFMG, Brazil (138 pp. ISBN: 85-900885-1-0. 1999).

Guidelines of Lake management. In: Straškraba, M., Tundisi, J.G. (Eds.), Reservoir Water Quality Management. 9. ILEC, p. 229.

Straškraba, M., Tundisi, J.G., 2000. Diretrizes para o gerenciamento de lagos- vol. 9: Gerenciamento da qualidade da água de represas. ILEC/ IIE, São Carlos 280 pp.

Su, H., Liu, H., Wang, L., Filippi, A.M., Heyman, W.D., Beck, R.A., 2014. Geographically adaptive inversion model for improving bathymetric retrieval from satellite multispectral imagery. IEEE Trans. Geosci. Remote Sens. 52:465-476. https://doi.org/10.1109/TGRS. 2013.2241772.

Sutton, T., Dassau, O., Sutton, M., 2009. A gentle introduction to GIS: brought to you with quantum GIS, a free and open source software GIS application for everyone [WWW document]. Princ. Geogr. Inf. Syst. An Introd. Textb. https://doi.org/10.1038/sj.bdj. 2011.132 Retrieved from. https://docs.qgis.org/2.2/pt_BR/docs/gentle_gis_ introduction/gnu_free_documentation_license.html.

Thornton, J., Steel, A., Rast, W., 1996. Water quality assessments - a guide to use of biota, sediments and water in environmental monitoring. In: Chapman, D. (Ed.), Water Quality Assessments - A Guide to Use of Biota, Sediments and Water in Environmental Monitoring, Second edition UNESCO/WHO/UNEP, p. 41.

Tong, C., Huang, J., Jia, Y., 2015. Small-Scale Spatial Variability of Soil Methane Production Potential and Porewater Characteristics in an Estuarine Phragmites australis Marsh. J. Coast. Res. 314:994-1004. https://doi.org/10.2112/JCOASTRES-D-14-00121.1.

U.S. Environmental Protection Agency (U.S.EPA), 1996. Method 3050B: Acid Digestion of Sediments, Sludges, and Soils (USA).

UNEP-IETC, 2001. United Nations environment programme - International Environment Technology Centre. Planejamento e gerenciamento de lagos e represas: uma abordagem integrada ao problema da eutrofização. RiMa, São Carlos (385 pp.).

United States Environmental Protection Agency - USEPA, 2005. Procedure for the derivation of equilibrium partitioning sediment benchmarks (ESBs) for the protection of benthic organ- isms: metal mixtures (cadmium, cooper, lead, nickel, silver and zinc). Office of Research and Development, Washington, DC (EPA-600-R-02-011).

United States Environmental Protection Agency - EPA, 2014. Cyanobacteria and Cyanotoxins: Information for Drinking Water Systems. EPA-810F11001 (11 pp.).

United States Environmental Protection Agency - EPA, 2016. Control and Treatment. https://www.epa.gov/.

Vallentyne, J.R., 1978. Introducción a la limnologia: los lagos y el hombre. Omega, Barcelona (169 pp.).

Van den Pol-van Dasselaar, A., van Beusichem, M.L., Oenema, O., 1999. Determinants of spatial variability of methane emissions from wet grasslands on peat soil. Biogeochemistry 44 (2), 221-223.

Varol, M., Sen, B., 2012. Assessment of nutrient and heavy metal contamination in surface water and sediments of the upper Tigris River, Turkey. Catena 92, 1-10.

Vaz, L.F., 1996. Classificação genética dos solos e dos horizontes de alteração de rochas em regiões tropicais. Solos e Rochas. 19, pp. 117-136.

Vidović, M.M., Rodić, M.N., Vidović, M.U., Trajković, I.S., Jovanić, S.Z., 2015. Assessment of the trophic status by monitoring of reservoir's water quality. J. Water Resour. Prot. 7: 1-13. https://doi.org/10.4236/jwarp.2015.71001.

von der Ohe, P.C., de Deckere, E., Pruss, A., Munoz, I., Wolfram, G., Villagrasa, M., Ginebreda, A., Hein, M., Brack, W., 2009. Toward an Integrated Assessment of the Ecological and Chemical Status of European River Basins. vol. 5(1):pp. 50-61. https://doi org/10.1897/IEAM 2008-043.1.

Wehr, J.D., Sheath, R.G., 2003. Freshwater Algae of North America: Ecology and Classification. Academic Press, San Diego.

Whately, M., Cunha, P.M. da, 2005. Como e por que São Paulo está perdendo este manancial: resultados do diagnóstico socioambiental participativo da Bacia Hidrográfica do Guarapiranga. São Paulo, Brazil (48 pp.).

Wood, A., Blackhurst, M., Hawkins, T., Xue, X., Ashbolt, N., Garland, J., 2015. Cost-effectiveness of nitrogen mitigation by alternative household wastewater management technologies. J. Environ. Manag. 150:344-354. http://dx.doi.org/10.1016/j.jenvman.2014. 10.002 .

World Health Organization, 1998. Copper. WHO, Geneva (Environmental Health Criteria $20^{\circ}$ ). ISBN 924157200 0s. ISSN 0250-863X. Retrieved from:. http://www.inchem org/documents/ehc/ehc/ehc200.htm.

Yamamoto, J.K., Landim, P.M.B., 2015. Geoestatística: conceitos e aplicações. Oficina de Textos, São Paulo 978-85-7975-077-9 215 pp.

Yoo, S.R., Carmichael, W.W., Hoehn, R.C., Hrudey, S.E., 1995. Cyanobacterial (Blue-green Algal) Toxins: A Resource Guide: AWWA Research Foundation and American Water Works Association.

Yousafzai, A.M., et al., 2012. Bioaccumulation of heavy metals in common carps: Implications for human health. Pak. J. Zool. 44 (2), 489-494.

Zagatto, P.A., 1995. Evaluation ecotoxicologique du reservoir Guarapiranga, SP, Brésil, en relation avec le probléme des alguestoxiqueset des algicides. Centre des Sciences de l'Énvironment, Université de Metz (Doctoral Thesis, (350pp.)). 